\title{
Risk factors for sports concussion: an evidence-based systematic review
}

Shameemah Abrahams, ${ }^{1}$ Sarah Mc Fie, ${ }^{1}$ Jon Patricios, ${ }^{2,3}$ Michael Posthumus, ${ }^{1}$ Alison V September ${ }^{1}$

${ }^{1}$ UCT/MRC Research Unit for Exercise Science and Sports Medicine, Department of Human Biology, University of Cape Town, South Africa, ${ }^{2}$ Morningside Sports Medicine and Sports Concussion South Africa, Johannesburg, South Africa, ${ }^{3}$ The Section of Sports Medicine, Faculty of Health Sciences, University of Pretoria, Pretoria, South Africa

Address for correspondence:

Dr Alison V September, UCT/MRC Research Unit for Exercise Science and Sports Medicine, University of Cape Town, PO Box 115, Newlands, 7725, South Africa

Phone: +27 216504559

Fax: +276867530

Email: Alison.September@uct.ac.za

SA and SM contributed equally to this work.

\section{Abstract}

Concussion is a common sports injury with approximately 1.6 - 3.8 million sport-related concussions reported in the US annually. Identifying risk factors may assist in preventing these injuries. This systematic review aims to identify such risk factors. Three electronic databases; ScienceDirect, PubMed and SpringerLink, were searched using the keywords "RISK FACTORS" or "PREDISPOSITION" in conjunction with "SPORT" and "CONCUSSION". 
Based on the inclusion and exclusion criteria, 13628 identified titles were independently analysed by two of the authors to a final list of 86 articles. Only articles with a level of evidence of I, II and III were included according to robust study design and data analysis. The level of certainty for each risk factor was determined. A high level of certainty for increased risk of a subsequent concussion in athletes sustaining more than one previous concussion was reported in 10 of 13 studies. Further, a high level of certainty was assigned to match play with all 29 studies reporting an increased concussion risk during matches. All other risk factors were evaluated as having a low level of certainty. Although several risk factors were identified from the appraised studies, prospective cohort studies, larger sample sizes, consistent and robust measures of risk should be employed in future research.

Keywords: sports concussion, risk factor, level of evidence, level of certainty

\section{Introduction}

Approximately 1.6-3.8 million concussions reported in the US are attributed to sports participation $^{1}$. Concussion, as defined in the Zurich 2012 consensus statement, is a pathophysiological process resulting in functional neurological impairments, as a consequence of forceful biomechanical impacts directly on or transmitted to the head, neck or face ${ }^{2}$. Deficits in cognitive, behavioural and motor control normally persist from 24 hours to 10 days after injury ${ }^{2,3}$. Individuals who sustain repeat concussions may experience longterm and severe damage such as chronic traumatic encephalopathy (CTE) ${ }^{4}$, decreased mental speed ${ }^{5}$ or memory dysfunction ${ }^{6}$.

Research suggests that concussion risk may be modulated by several factors. Studies often report sports concussion occurring more frequently in females, younger athletes and those 
with a history of previous concussion ${ }^{7-10}$. However, the exact aetiology of concussion still remains unclear. The identification of risk factors, which predispose an athlete to concussion, may further our understanding of the underlying mechanisms of concussion and aid in the improvement of prevention strategies. Moreover, recent papers highlight CTE as a potentially significant consequence of repeated head trauma in contact sports ${ }^{4,11,12}$, making the prevention of concussion that much more important. Therefore, the aim of this evidence-based systematic review is to provide a descriptive summary of the literature, highlight potential risk factors for concussion and further our knowledge of concussion susceptibility.

\section{Methods}

\section{Search Strategy}

Published articles that examined potential risk factors for sport-related concussion were reviewed following the PRISMA (Preferred Reporting Items for Systematic Reviews and Meta-Analyses) guidelines ${ }^{13}$. Three electronic databases; ScienceDirect, PubMed and SpringerLink, were searched using the keywords "RISK", "RISK FACTOR" or "PREDISPOSITION" in conjunction with "SPORT" and "CONCUSSION". The database search was limited to articles published between January 1980 and April 2013. Review articles and book chapters were initially included to provide a larger selection of articles from the reference lists. A three-step method was used to identify the articles that were reviewed. The titles, abstracts and full texts were independently screened by two of the authors (SA and SM). Articles were excluded at each step if unrelated to the topic or met the exclusion criteria outlined in Table 1.1. 
Table 1.1: A summary of the exclusion criteria applied by two of the authors (SA and SM) to identify relevant articles

\section{Exclusion criteria}

1. Commentaries, letters, editorials, conference proceedings, case reports, conference abstracts or nonpeer reviewed articles.

2. Studies examining non sport-related concussions.

3. Studies which only include concussions when a loss of consciousness occurred.

4. Studies of severe traumatic brain injury (e.g. fractures, lesions).

5. Studies of animal or biomechanical models of brain injury.

Two rounds of reviewing the literature, using the three-step method in each round, were performed. Round one pertained to the review of articles from the search results of the databases and round two involved reviewing the reference lists of identified articles from round one. Thereafter, the identified articles from rounds one and two were stringently appraised according to the inclusion criteria summarised in Table 1.2.

Table 1.2: The inclusion criteria used to select articles to be incorporated in the systematic review

\section{Inclusion criteria}

1. The article must include original data.

2. The article must be published in English or have been translated into English.

3. The article must include a minimum of one potential risk factor for sport concussion.

4. The article must include a point or risk estimate (e.g. odds ratio), with the $95 \%$ confidence interval (Cl) and/or p-value obtained from chi-square tests, or the necessary data to calculate these measures of association. 


\section{Data extraction}

The study design, study population and results were reviewed from the identified articles in the appraisal step. Studies reporting risk estimates including relative risk (RR), odds ratio $(\mathrm{OR})$, incidence rate ratio (IRR) and hazard ratio $(H R)$ were identified. These risk estimates are routinely used as measures of injury risk ${ }^{14,15}$. In the case that studies had not reported these measures, the IRR including $95 \% \mathrm{Cl}$ was calculated ${ }^{16}$ by two of the authors (SA and SM) and denoted as IRR*. Similarly, in cases where stylistically appropriate, the inverse of the risk estimate and confidence interval was calculated and an asterisk was assigned. Notably, certain studies reporting a chi-square $p$-value only were included in the appraisal as it is a measure of statistical significance but is limited in interpretation and estimation of risk.

\section{Level of evidence and certainty}

Table 1.3: Level of evidence $(I-V)$ definitions used for study evaluation, as previously defined ${ }^{17,18}$ 
The level of evidence was determined for each article selected by the inclusion and exclusion criteria. The level of evidence is a ranking system for research articles and was determined by two of the authors (SA and SM) using previously described definitions (Table $1.3)^{17-19}$. Only articles with a level of evidence of I, II and III were included in the final appraisal step.

Subsequently, articles investigating the same risk factor were grouped and, from an overall analysis of the articles, the level of certainty that each risk factor is associated with increased risk of concussion was calculated. The definitions used to determine low, moderate and high level of certainty, as originally defined by the US Preventative Services Task Force ${ }^{20}$ and modified by Posthumus et al. ${ }^{17}$ are detailed in Table 1.4.

Table 1.4: Level of certainty (High - Low) definitions used for risk assessment as previously defined by Sawaya et al. ${ }^{20}$ and modified by Posthumus et al. ${ }^{17}$

Level of certainty Definition

The available evidence includes consistent results from level I studies. These studies provide a good estimate of risk and are unlikely to be strongly affected by future studies.

The available evidence includes sufficient evidence to determine that there is risk associated with the injury, but confidence in the estimate is constrained by factors Moderate such as the sample size and quality of studies, as well as inconsistency of findings across individual studies. As more information becomes available, the magnitude of risk could change or even alter the conclusion.

The available evidence is insufficient to assess risk. Evidence is insufficient because of Low the limited number or size of studies, and inconsistency of findings across individual studies. More information may allow an estimation of risk. 


\section{Results and Discussion}

The article selection process is outlined in Figure 1. In total, the analyses of the 86 appraised studies identified 14 risk factors for sports concussion which are discussed below and summarised in Tables 2 and 3.

\subsection{Intrinsic Risk Factors}

\subsubsection{Previous Concussion}

A history of previous concussion was measured as one or more sports concussions sustained prior to the observation period of the specific study. Ten of the thirteen studies reported an increased risk of concussion in those athletes with a history of previous concussion (Table 2.1.1).

Four studies reported an increased risk of concussion in junior ice hockey players who had a history of previous concussions ${ }^{21-24}$. Similarly, a greater risk was also observed in rugby union players with one or more than two previous concussions ${ }^{25}$. Studies investigating the risk of previous concussions in American football ${ }^{26-29}$ found a three- to six-fold increased risk in sustaining a subsequent concussion. Further, a cohort of athletes participating in various sports with at least one previous concussion were at a three-fold greater risk of sustaining a concussion compared to those who had no previous concussion ${ }^{30}$. However, a small number of concussions were reported $(n=28)$, which constrains the interpretation of the results. 


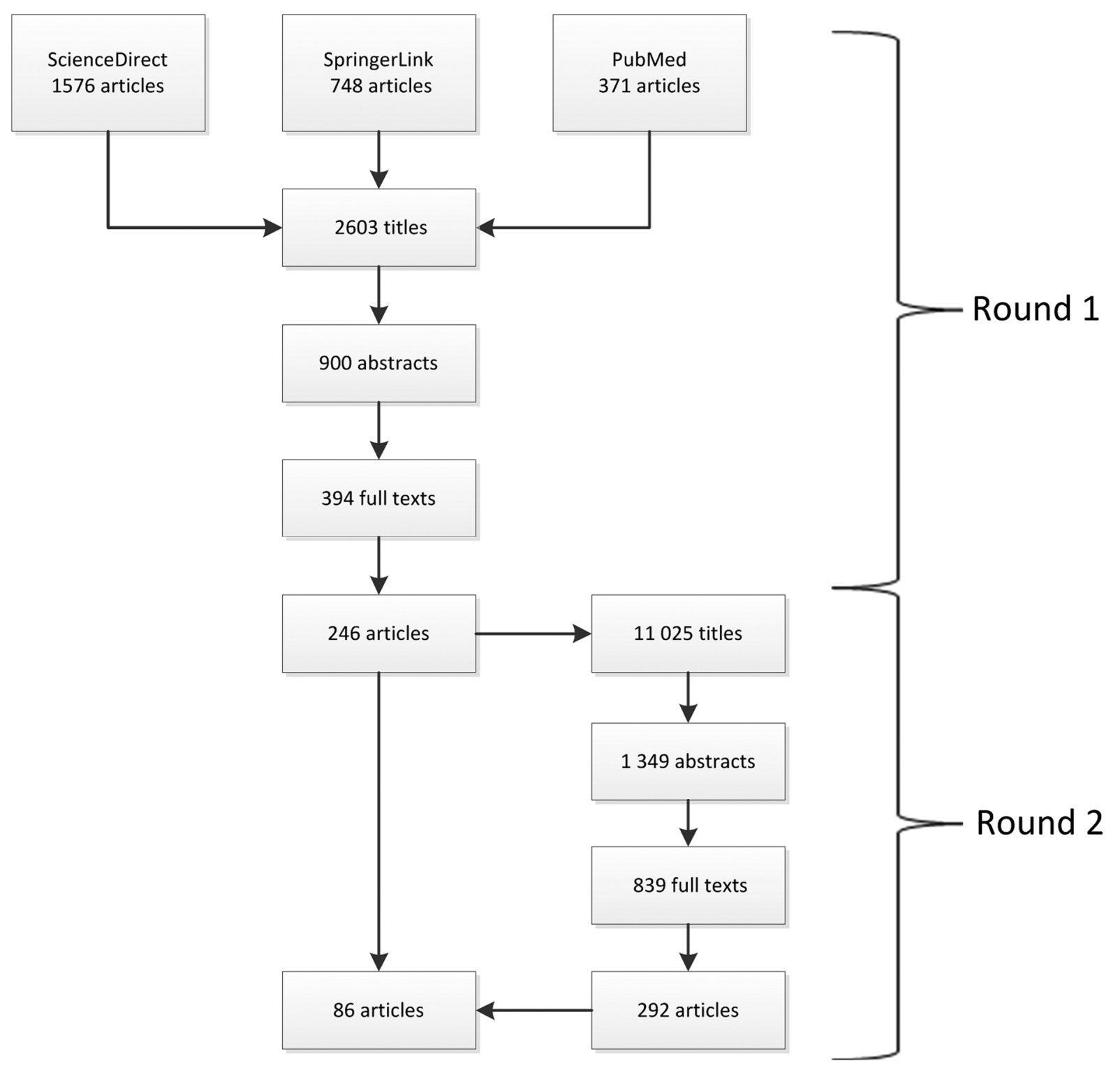

Figure 1: Outline of literature search procedure and article selection. In round one 2603 articles were identified using the three electronic database searches. After the title, abstract and full text screening steps the number of articles was reduced to 900,394 and 246 articles respectively. From the reference lists of the 246 full text selected articles, 11025 articles were extracted. Using the same screening steps as round one the 11025 articles were reduced to 1349 after title, 839 after abstract and 292 after full text screening. Inclusion and exclusion criteria were applied, as described in the methods, resulting in a final selection of 86 articles which were critically appraised. 
Three studies of American football and soccer players showed two- to 11-fold increased odds of sustaining a concussion in those with a history of previous concussion. However, these studies lacked a $95 \% \mathrm{Cl}$ resulting in a meaningless risk

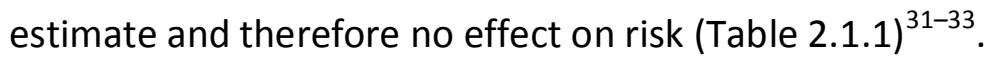

All three studies reporting no effect are lower quality retrospective studies (level of evidence of II and III). Whereas the 10 studies showing an increased risk were welldesigned and high quality prospective studies with four denoted as level I and the remaining were level II. No studies found a decreased risk. Notably, studies reporting concussion history are often constrained by the unreliability of patient recall, however overall he published studies provide a good estimate of risk and are unlikely to be affected by future studies. Therefore, a history of previous concussion increases concussion risk with a high level of certainty.

\subsubsection{Sex}

Twenty-three studies investigated whether there was a difference in concussion risk between male and female athletes (Table 2.1.2). Four studies found males to be at increased risk, ten studies showed females had a greater risk of concussion, and nine studies found no association.

Males were at a greater risk in youth alpine sports $^{35}$, youth American football ${ }^{36}$, lacrosse $^{37}$ and when comparing different sport types ${ }^{38}$. However, comparing different sport types, between sexes, introduces a bias as males tend to play highcollision sports with increased concussion risk. Further, males are often more willing 
to take more risks within the same sport ${ }^{35}$. More studies are required to confidently assess sex differences in male dominated sports, such as rugby and American football.

Females were found to have a 1.5 to 2.5 fold greater concussion risk in various levels of soccer ${ }^{33,39-42}$. Two studies found no significant difference between male and female soccer players, but included only five and 29 concussions, respectively and therefore lacked statistical power. Females had a 1.5 and three-fold higher concussion risk in the five studies on basketball populations ${ }^{39,41,43-45}$. Four studies compared female softball and male baseball players with three studies reporting greater risk in softball players ${ }^{39,46,47}$. Several possible reasons for increased concussion susceptibility in females have been proposed. Female soccer players have been found to have increased head acceleration during impacts compared to males, indicative of decreased neck strength and effective head mass ${ }^{48,49}$. It has been suggested that the increased head to ball ratio in female soccer players may also play a role $\mathrm{s}^{50}$. Another reason for higher concussion rates in females may be their increased willingness to report injuries ${ }^{51}$.

Nine studies observed no difference in concussion risk between sexes in taekwondo ${ }^{52-54}$, soccer ${ }^{55,56}$, collegiate rugby ${ }^{57}$, lacrosse ${ }^{39,41}$ and when comparing different sport types ${ }^{58,59}$. A possible confounding variable when comparing sex differences in lacrosse; is the difference in protective equipment and rules with physical contact reduced in the female game. 
The results from these studies suggest that in sports where rules and physicality are more equal between sexes, such as soccer and basketball, females appear to be at greater risk. However, when all sports are collectively analysed, there is a low level of certainty that sex is a risk factor for concussion. Future studies should include measures of exposures so that a reliable correlation between sex and concussion risk may be established.

\subsubsection{Age}

Fourteen studies examined whether concussion risk was modulated by age (Table 2.1.3). Eight studies identified the older age group to be associated with greater concussion risk; conversely three studies found the younger age group at greater risk and three studies found no effect of age.

Collegiate cheerleaders were at a three-fold greater concussion risk compared to those younger than 18 years old, although only 23 concussions were recorded in 9022 participants $^{65}$. An increased concussion risk in collegiate athletes is not exclusive to cheerleaders. A level III retrospective study, investigating over 3700 sport concussions for several sports, found an increased likelihood of concussion occurring in 10-14 and 15-18 year olds compared to the younger cohort (5-10 years $)^{58}$. Furthermore, significantly higher concussion rates were observed in 11-16 year old ice hockey players compared to $9-10$ years ${ }^{66}$. However, this finding is most likely confounded by the effect of body checking only permitted in age groups above 10 years. 
Contrastingly, children younger than six years old were at greater risk of concussion in roller skating, ice skating and rollerblading ${ }^{67}$. In a large scale level I prospective cohort study, including over 1000 concussions, high school football players were at an increased concussion risk compared to collegiate players ${ }^{68}$.

Three studies found no difference in concussion risk between age groups when comparing high school to adult club rugby union ${ }^{69}, 11 / 12$ to $13 / 14$ year old ice hockey players ${ }^{23}$ and male lacrosse high school athletes ${ }^{70}$.

Although more studies reported greater risk in the older cohort, only one of these studies was a high quality level $I^{43}$ and the remaining seven were level II or III mainly due to small number of concussions and a weaker study design (Table 2.1.3). The outcomes of the appraised studies indicate that age may play a role in concussion risk; however contrasting findings confers a low level of certainty for concussion risk.

\subsubsection{Genetics}

Genetic association studies on concussion risk are limited. The apolioprotein E $(A P O E)$ gene is, thus far, the only genetic marker investigated with regard to concussion risk. Only one of the three appraised studies showed an increased concussion risk (Table 2.1.4). All three studies investigated the association between the $A P O E$ gene and concussion. The $A P O E$ gene encodes for the lipid carrier protein, apo $E$, which has been implicated in nerve damage ${ }^{90,91}$. The TT genotype of the $186 \mathrm{bp}$ promoter variant of the APOE gene was significantly associated with a history of one or more previous concussions in intercollegiate soccer and American 
football $^{92}$. The two studies that observed no association between the APOE \&4 allele, concussion history $^{93}$ and multiple concussions ${ }^{30}$, recorded a small number of concussions. Therefore, the absence of an association must be interpreted cautiously. As a consequence of too few studies and none with a high level of evidence of I, the genetic risk for concussion was given a low level of certainty.

\subsubsection{Behaviour}

A preference for aggressive action on the field was used as a measure of athlete behaviour in the four high quality level I and II studies (Table 2.1.5). Three studies investigated concussion risk and player behaviour in ice hockey, an aggressive collision sport ${ }^{89}$. Athletes who played ice hockey for tension and aggression relief were significantly more likely to sustain a concussion compared to players with less aggressive tendencies ${ }^{86}$. The other two prospective cohort studies on ice hockey showed no effect of aggressive behaviour preference and experience in an aggressive tactic on concussion risk ${ }^{21,23}$.

The Korean martial art of taekwondo has developed into a full contact sport involving permissible contact to the head ${ }^{94}$. Taekwondo athletes who used defensive blocking skills during a competition showed a significantly decreased concussion risk $^{54}$.

Although there is an implication for aggressive behaviour (including legal sport actions) increasing concussion risk in sports involving head and neck contact, too few 
high quality studies results in a low certainty level assigned to behaviour as a concussion risk.

\subsection{Extrinsic Risk Factors}

\subsubsection{Match vs. Practice}

All of the 29 studies indicated that there was a higher risk of concussion in matches compared to practices (Table 2.2.1). The increased risk of high impact collisions in match play compared to practices, is the primary reason for the increased risk ${ }^{34}$. There was a wide range of risk estimate values, which was often due to low numbers of concussions in training sessions skewing the statistics. However all studies reflected an increased concussion risk in matches and seem unlikely to be altered by future research. Therefore, match play was assigned a high level of certainty to increase concussion risk.

\subsubsection{Match period}

Two studies examined the period of the match as a potential risk factor for concussion (Table 2.2.2). The first study found there were significantly more concussions in the second compared to the third period in elite ice hockey games ${ }^{103}$. The second study in found no difference in concussion rates between the first and second halves of professional rugby league football ${ }^{64}$. Due to the limited number of studies we assign a low level of certainty to the time of the match as a risk factor. 


\subsubsection{Mechanism of injury}

In most studies reporting on the mechanism of injury for concussion, a collision with another player either accidently or illegally was often the mechanism of concussion in various sports ${ }^{42,56,95,96}$. However, a major limiting factor of these studies is the lack of risk estimation with often only the percentage or proportion of concussion reported. Therefore, only two prospective cohort level II studies were identified (Table 2.2.3 $)^{97,98}$. One study found a significantly different concussion incidence between unintentional and intentional collisions $(p=0.04)^{97}$. Specifically, a hit to the head or helmet was a significantly common mechanism of concussion injury in ice hockey $(p=0.007)$, soccer $(p<0.0001)$ and American football players $(p<0.0001)^{98}$. However, no risk estimate was measured in both studies and no measure of concussion risk could be performed.

Although collision of the head against a surface is viewed as the common mechanism of concussion injury, to our knowledge no high quality studies have ascertained risk estimates for mechanism of sustaining a concussion. The poor data analysis and lack of risk estimation results in a low certainty level for mechanism of injury and concussion risk.

\subsubsection{Playing position}

Playing position as a risk factor for concussion is often investigated in American football, ice hockey and rugby. Six studies, two of which are high quality level I studies, showed no effect of playing position on concussion risk. An increased and decreased risk for specific playing positions was reported in two studies with a level 
of evidence of II and I, respectively (Table 2.2.4). The recalculated IRR* showed that the offensive quarterback position, in American football, had the highest risk of sustaining a concussion compared to all other playing positions. Specifically, quarterbacks had a 1.7- to five-fold increase in concussion risk compared to other offensive positions (range of IRR*: $1.72,95 \% \mathrm{Cl} 1.14-2.60$ to $5.59,95 \% \mathrm{Cl} 3.90-$ $8.02)^{60}$, with an exception when compared to the offensive wide receiver (quarterback vs. wide receiver IRR*: $1.32,95 \% \mathrm{Cl} 0.96-1.81$ ), as well as an almost two- and three-fold increased risk compared to defensive positions (range of IRR*: $1.74,95 \% \mathrm{Cl} 1.29-2.35$ to $3.68,95 \% \mathrm{Cl} 2.61-5.20)^{60}$. In contrast, two American football studies found no effect of individual playing positions on concussion risk ${ }^{29,61}$.

Ice hockey has three playing position categories; defence, forwards and goalie. One of the three ice hockey studies reported an almost three-fold decreased risk of concussion in goalies compared to the defence and forward units. Conversely, no difference in concussion risk was observed when comparing goalies against the defence and forwards in the top $60 \%$ of competitive youth and professional ice hockey players ${ }^{21,62}$. No risk estimation could be determined for the latter study ${ }^{62}$ as only chi-squared values were reported without risk estimate.

Rugby league and union differ in rules and playing style but the types of playing positions are similar with two broad classifications; forwards and backs. Both rugby studies reported no effect of playing position on risk. However, few concussions were reported explaining the absence of a risk effect ${ }^{63,64}$. 
Due to inconsistent findings among the reviewed studies, the certainty that playing position is a risk factor for concussion is low.

\subsubsection{Playing level}

The six articles assessing concussion risk in different playing levels, within the same age-group, displayed varied findings (Table 2.2.5). Two prospective cohort studies (level I and II) found concussion rates increased in descending divisions of college American football. Guskiewicz et al. ${ }^{68}$ found that there was a lower risk in the $1^{\text {st }}$ division compared to the $2^{\text {nd }}$ and $3^{\text {rd }}$ divisions. Likewise, another study showed concussion rates were lower in the $1^{\text {st }}$ and $2^{\text {nd }}$ compared to the $3^{\text {rd }}$ division ${ }^{29}$. These authors proposed that the increased risk at lower playing levels may be due to poor quality of protective equipment, decreased skill levels or players having to play both offensive and defensive positions ${ }^{68}$. Conversely, a study on professional rugby league players found increasing playing level tended to increased concussion risk but this failed to reach significance ${ }^{64}$. Three studies found no difference in concussion risk between different playing levels. Stephenson et al. ${ }^{87}$ found no difference between the $1^{\text {st }}$ team and the A-teams of professional rugby league teams. Two studies by Emery et al. ${ }^{21,22}$ found no difference between ice hockey players grouped on ability.

From the selected studies no consistency in results was found, therefore a low level of certainty was given to playing level as a risk factor for concussion. Further level I prospective cohort studies are required to improve the level of evidence. 


\subsubsection{Protective equipment}

The ability of protective gear to reduce concussion risk was investigated in 13 studies (Table 2.2.6). Six studies investigated the effect of mouth guards, five on padded headgear and three on the effect of face visors to reduce concussions risk.

Mouth guards have often been shown to be protective against orofacial injuries ${ }^{71-73}$, but their effect on concussion is less clear. Surprisingly, a trend for increased concussion risk was shown in American football players wearing mouth guards ${ }^{33}$. A possible explanation may be risk compensation, which occurs when protective equipment use induces an increase in risky behaviour that may negate the possible effect of protective equipment ${ }^{74,75}$. Mouth guard use was found to have no significant effect on concussion risk in five of the six studies ${ }^{63,71,72,76,77}$. However, a level II study showed concussion rates decrease after introducing customised mouth guards in 28 American football players ${ }^{76}$. There are several methodical criticisms of the study. Specifically, players were older when they used the customised mouth guards and there was an overrepresentation in concussion rates when using standard mouth guards as both match and practice injuries were included compared to only match injuries for customised mouth guards. The relation between mouth guards and concussion prevention is constrained by the use of static cadaver skulls to mimic dynamic biomechanical and biological processes ${ }^{78}$, the limited evidence for an association between force transduction and concussion induction ${ }^{79}$ and few sport concussions result from mandibular impact ${ }^{77}$. 
Padded headgear has been shown to decrease the risk of abrasions and lacerations, but its effectiveness in preventing concussion needs to be determined ${ }^{80,81}$. In a level II retrospective cohort of adolescent soccer players, a trend for padded headgear users showed a 2.5 -fold greater concussion risk ${ }^{40}$. This finding needs to be interpreted cautiously as no $95 \% \mathrm{Cl}$ was given and concussions were based on recall of symptoms. There is also biomechanical evidence that commercially available soccer head gear products do not have the structural ability to prevent concussions $^{82}$. Two studies indicated that head gear had no significant effect on concussion risk in rugby union players ${ }^{72,83}$. Conversely, in a large level II prospective cohort study of adult amateur rugby, the use of padded headgear was found to decrease concussion risk ${ }^{25}$. Similarly, in a level I study that included 81 concussions, headgear was found to significantly decrease concussion risk in professional rugby union teams ${ }^{63}$. Therefore, it seems as though large cohorts and more level I studies may be required to see an effect on concussion risk.

Two studies observed the effects of facial protection on concussions in ice hockey. No difference was found in concussion rates in players wearing full, partial or no facial protection ${ }^{84,85}$. One study found that players who complained that the face mask obscured their vision were five times more likely to be concussed ${ }^{86}$.

In summary, the use of face visors showed no concussion protection and although headgear and mouth guards may play a role in concussion risk, the overall effect of protective equipment is inconclusive. Thus, a low level of certainty was given for protective equipment as a concussion risk. 


\subsubsection{Body checking}

Body checking, an aggressive blocking tactic, is thought to increase injury risk, especially in junior players. Four, of the six identified studies, showed a greater concussion risk due to body checking in ice hockey players (11-16 years) (Table 2.2.7) $21,24,88$. A prospective study of 986 ice hockey players reported an increased concussion risk for those permitted to body check (13-14 and 15-16 years) compared to those who were not (9-10 years). However, the age difference between the comparative groups confounds the effect of checking on concussion risk ${ }^{66}$. Although prohibiting body checking at younger age groups are thought to increase injury risk due to poor technique ${ }^{89}$, Emery et al. ${ }^{23}$ found no difference in concussion risk between players with body checking experience (checking allowed at 9-10 years old) and novices (no checking allowed).

Only two of the five studies on body checking were of a high level of evidence of I whereas the remaining studies were given a level of evidence of II and III. A limitation is that most studies lacked age-matched comparative groups, thus a low level of certainty was given for body checking as a concussion risk estimate.

\subsubsection{Environment}

Three studies observed whether environmental factors affect the risk of concussion (Table 2.2.83). Two level II prospective studies compared concussion risk on natural and artificial grass in elite soccer players. Artificial surfaces are firmer and therefore increase speed of play, possibly resulting in higher impact collisions ${ }^{99}$. In addition, artificial surfaces are often harder, which may increase the force of impact if the 
head collides with the ground ${ }^{100}$. Neither study found a significant difference in concussion risk between the two surfaces ${ }^{101,102}$. However, Bjornboe et al. ${ }^{101}$ noted a tendency for match concussion to be reduced on the artificial turf. Both studies, however, lacked the large numbers of concussion often required to identify significant associations.

A large scale level II retrospective study found that youth football-related concussions were more likely to occur at school compared to at a recreational facility or at home $e^{36}$. Due to the limited number and size of studies observing the effect of playing environment, a low level of certainty was assigned.

\subsection{Other}

Several miscellaneous risk factors were examined (Table 2.3). Rugby union players with less training and above average body mass index had higher concussion rates ${ }^{104}$. Contrastingly, junior ice hockey players in the lowest body weight quartile were at an increased concussion risk $^{24}$. This may be due to the aggressive nature of ice hockey in which players' use their own body weight to gain advantage resulting in heavier players often knocking down their lighter opponents. In wheelchair basketball, players that used a wheelchair as their primary form of locomotion sustained less concussions, leading to speculation that those with less severe disability and more physical ability travelled faster potentially increasing concussion risk $^{45}$. It has been proposed that athletes with low physical fitness become fatigued earlier in the game, leading to inability to react efficiently to the dynamic game environment and increasing injury risk ${ }^{28}$. Although only trends for fewer concussions were reported in youth 
ice hockey winning teams ${ }^{22}$ and football players with low aerobic fitness ${ }^{28}$, physicality may influence concussion risk.

Interestingly, a trend was identified between the temporal side of the head and concussion incidence in soccer and football players ${ }^{98}$. Impacts on the side of the head are often outside of the player's field of vision limiting the ability to engage the neck muscles necessary to decrease head acceleration after impact, thus increasing concussion risk. The side of the head may also be biomechanically more vulnerable to an impact force ${ }^{98}$. As a consequence of insufficient research on these potential risk factors, a low certainty was assigned to each (Table 2.3). 
Table 2: Research studies appraised for risk factors of sports concussion

\begin{tabular}{|c|c|c|c|c|c|c|c|}
\hline Risk factor & Article & $\begin{array}{l}\text { Study } \\
\text { design }\end{array}$ & $\begin{array}{l}\text { Population } \\
\text { (cohorts } \\
\text { compared) }\end{array}$ & $\begin{array}{l}\text { Number of } \\
\text { concussions }\end{array}$ & Results & $\begin{array}{l}\text { Level of } \\
\text { evidence }\end{array}$ & Level of certainty \\
\hline \multicolumn{8}{|c|}{ Intrinsic Risk Factors } \\
\hline \multirow[t]{8}{*}{ 2.1 Previous concussion } & \multicolumn{6}{|c|}{ Increased risk } & \multirow[t]{8}{*}{ High } \\
\hline & $\begin{array}{l}\text { Emery et al. } \\
2010^{21}\end{array}$ & PC & $\begin{array}{c}\text { Youth ice hockey } \\
\text { players }\end{array}$ & 101 & $\begin{array}{c}\text { IRR: } 2.14(95 \% \mathrm{Cl} \\
1.28-3.55)\end{array}$ & $\mathbf{I}$ & \\
\hline & $\begin{array}{c}\text { Emery et al. } \\
2011^{22}\end{array}$ & PC & $\begin{array}{c}\text { Youth ice hockey } \\
\text { players }\end{array}$ & 183 & $\begin{array}{c}\text { IRR: } 2.04(95 \% \mathrm{Cl} \\
1.46-2.86) \\
p<0.001\end{array}$ & $\mathbf{I}$ & \\
\hline & $\underset{27}{\text { Zemper }} 2003$ & PC & $\begin{array}{l}\text { High school \& } \\
\text { college American } \\
\text { football players }\end{array}$ & 572 & $\begin{array}{c}\text { College RR: } 5.30 \\
\text { (95\% Cl } 4.3-6.6) \\
\text { High school RR: } \\
6.60(95 \% \mathrm{Cl} 5.0- \\
8.8)\end{array}$ & $\mathbf{I}$ & \\
\hline & $\begin{array}{l}\text { Guskiewicz et } \\
\text { al. } 2003^{29}\end{array}$ & PC & $\begin{array}{c}\text { Collegiate } \\
\text { American football } \\
\text { players }\end{array}$ & 196 & $\begin{array}{c}\text { Two previous } \\
\text { concussions IRR: } \\
2.50(95 \% \mathrm{Cl} 1.5- \\
4.1) \\
\text { >three previous } \\
\text { concussions IRR: } 3 \\
(95 \% \mathrm{Cl} 1.6-5.6)\end{array}$ & $\mathbf{I}$ & \\
\hline & $\begin{array}{l}\text { Hollis et al. } \\
2009^{25}\end{array}$ & PC & $\begin{array}{l}\text { Amateur rugby } \\
\text { union players }\end{array}$ & 347 & $\begin{array}{c}\text { one previous } \\
\text { concussion IRR: } \\
1.75(95 \% \mathrm{Cl} 1.11 \\
-2.76) \mathrm{p}=0.016 \\
\text { > two previous } \\
\text { concussions IRR: } \\
1.65(95 \% \mathrm{Cl} 1.11 \\
-2.45) \mathrm{p}=0.013\end{array}$ & II & \\
\hline & $\begin{array}{l}\text { Schneider et } \\
\text { al. } 2013^{24}\end{array}$ & PC & $\begin{array}{c}\text { Youth ice hockey } \\
\text { players }\end{array}$ & 175 & $\begin{array}{c}\text { IRR: } 2.06(95 \% \mathrm{Cl} \\
1.52-2.80)\end{array}$ & II & \\
\hline & Kontos et al. & PC & High school & 23 & OR: $3.71(95 \% \mathrm{Cl}$ & II & \\
\hline
\end{tabular}




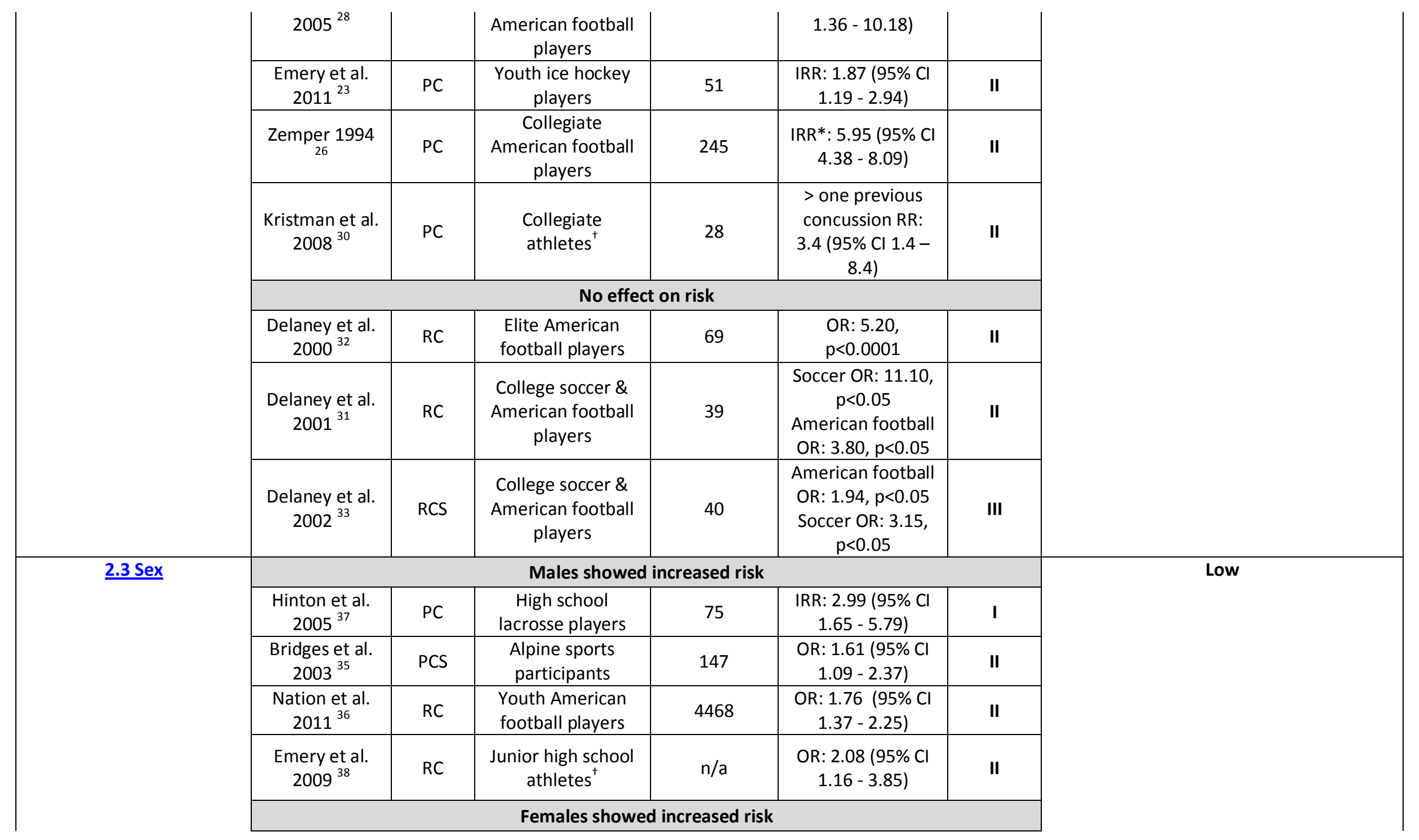




\begin{tabular}{|c|c|c|c|c|c|}
\hline $\begin{array}{l}\text { Lincoln et al. } \\
2011^{39}\end{array}$ & PC & $\begin{array}{l}\text { High school soccer, } \\
\text { basketball, softball } \\
\text { \& baseball players }\end{array}$ & 2651 & $\begin{array}{c}\text { Basketball IRR: } \\
1.70 \text { (95\% Cl } 1.3 \text { - } \\
2.2) \\
\text { soccer IRR: } 2.1 \\
(1.6-2.6) \\
\text { Baseball/softball } \\
\text { IRR: } 1.90(95 \% \mathrm{CI} \\
1.2-3.0)\end{array}$ & I \\
\hline $\begin{array}{c}\text { Gessel et al. } \\
2007^{43}\end{array}$ & PC & $\begin{array}{l}\text { Youth basketball \& } \\
\text { soccer football } \\
\text { players }\end{array}$ & 878 & $\begin{array}{c}\text { Soccer IRR: } 1.68 \\
(95 \% \mathrm{Cl} 1.08- \\
2.60) \mathrm{p}=0.03 \\
\text { Basketball IRR: } \\
2.93(95 \% \mathrm{Cl} 1.64 \\
-5.24) \mathrm{p}<0.01 \\
\end{array}$ & I \\
\hline $\begin{array}{l}\text { Castile et al. } \\
2012^{46}\end{array}$ & $\mathrm{RC}$ & $\begin{array}{l}\text { High school } \\
\text { athletes }^{+}\end{array}$ & 2402 & $\begin{array}{c}\text { Soccer IRR*: } 1.5 \\
\text { (95\% Cl } 1.2-1.8) \\
\text { Basketball IRR*: } \\
1.96(95 \% \mathrm{Cl} 1.5 \text { - } \\
2.5) \\
\text { Baseball/softball } \\
\text { IRR*: } 2.68(95 \% \mathrm{Cl} \\
1.75-4.1)\end{array}$ & II \\
\hline $\begin{array}{l}\text { Marar et al. } \\
2012^{112}\end{array}$ & $\mathrm{RC}$ & $\begin{array}{l}\text { Male \& female } \\
\text { high school } \\
\text { athletes }^{+}\end{array}$ & 1936 & $\begin{array}{c}\text { Soccer IRR: } 1.79 \\
\text { (95\% Cl } 1.40- \\
2.29) \\
\text { Baseball/softball } \\
\text { IRR: } 3.2(95 \% \mathrm{Cl} \\
1.97-5.19)\end{array}$ & II \\
\hline $\begin{array}{c}\text { Deitch et al. } \\
2006^{44}\end{array}$ & $\mathrm{RC}$ & $\begin{array}{c}\text { Male \& female } \\
\text { professional } \\
\text { basketball players }\end{array}$ & 51 & $\begin{array}{c}\text { IRR*: } 3.00(95 \% \mathrm{Cl} \\
1.5-6.0)\end{array}$ & II \\
\hline $\begin{array}{l}\text { Covassin et al. } \\
\qquad 2003^{41}\end{array}$ & $\mathrm{RC}$ & $\begin{array}{l}\text { Collegiate } \\
\text { athletes }^{+}\end{array}$ & 304 & $\begin{array}{c}\text { Basketball IRR*: } \\
1.52 \text { (95\% Cl } 1.06 \\
-2.19) \\
\text { Soccer IRR*: } 1.58 \\
\text { (95\% Cl } 1.23-\end{array}$ & II \\
\hline
\end{tabular}




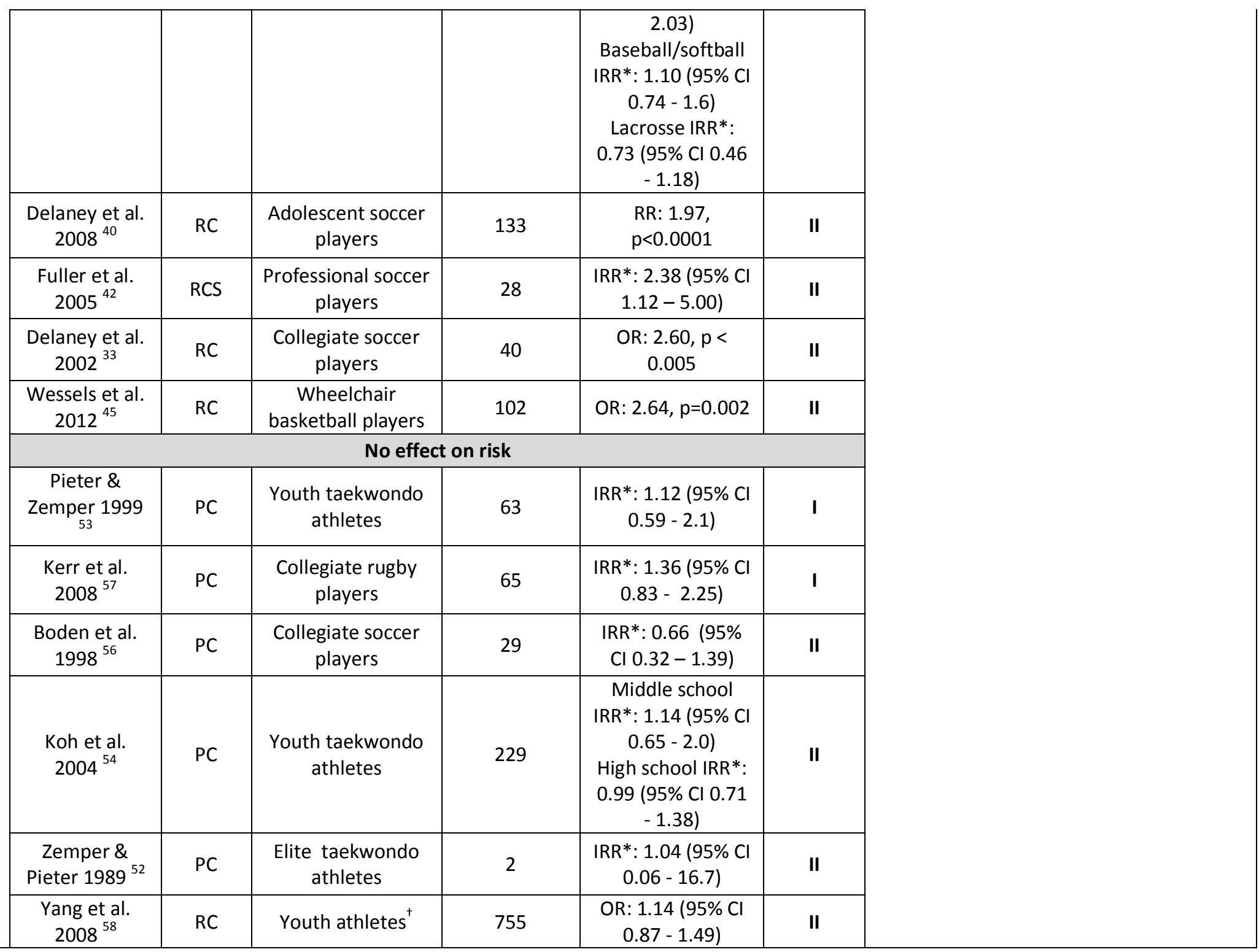




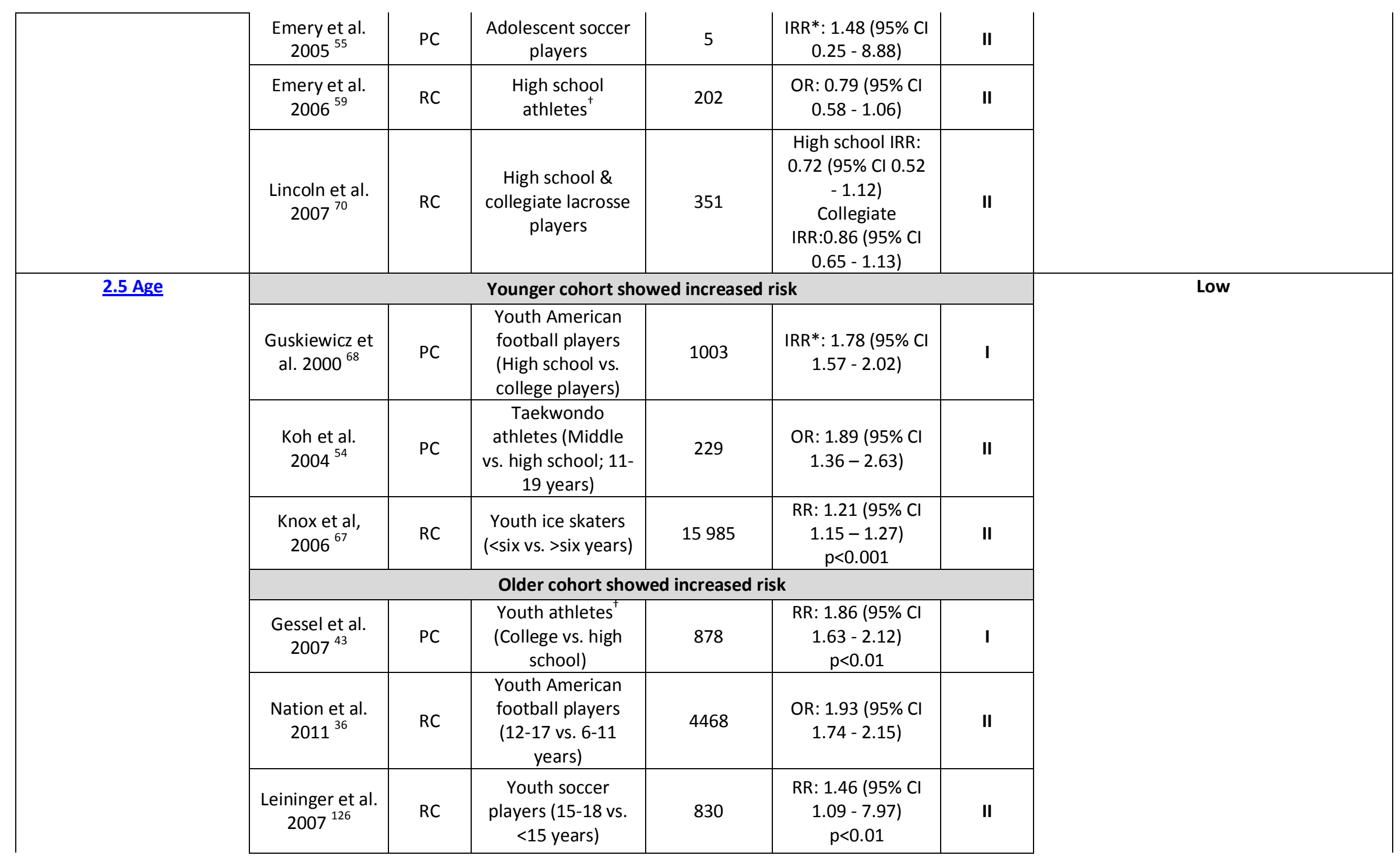




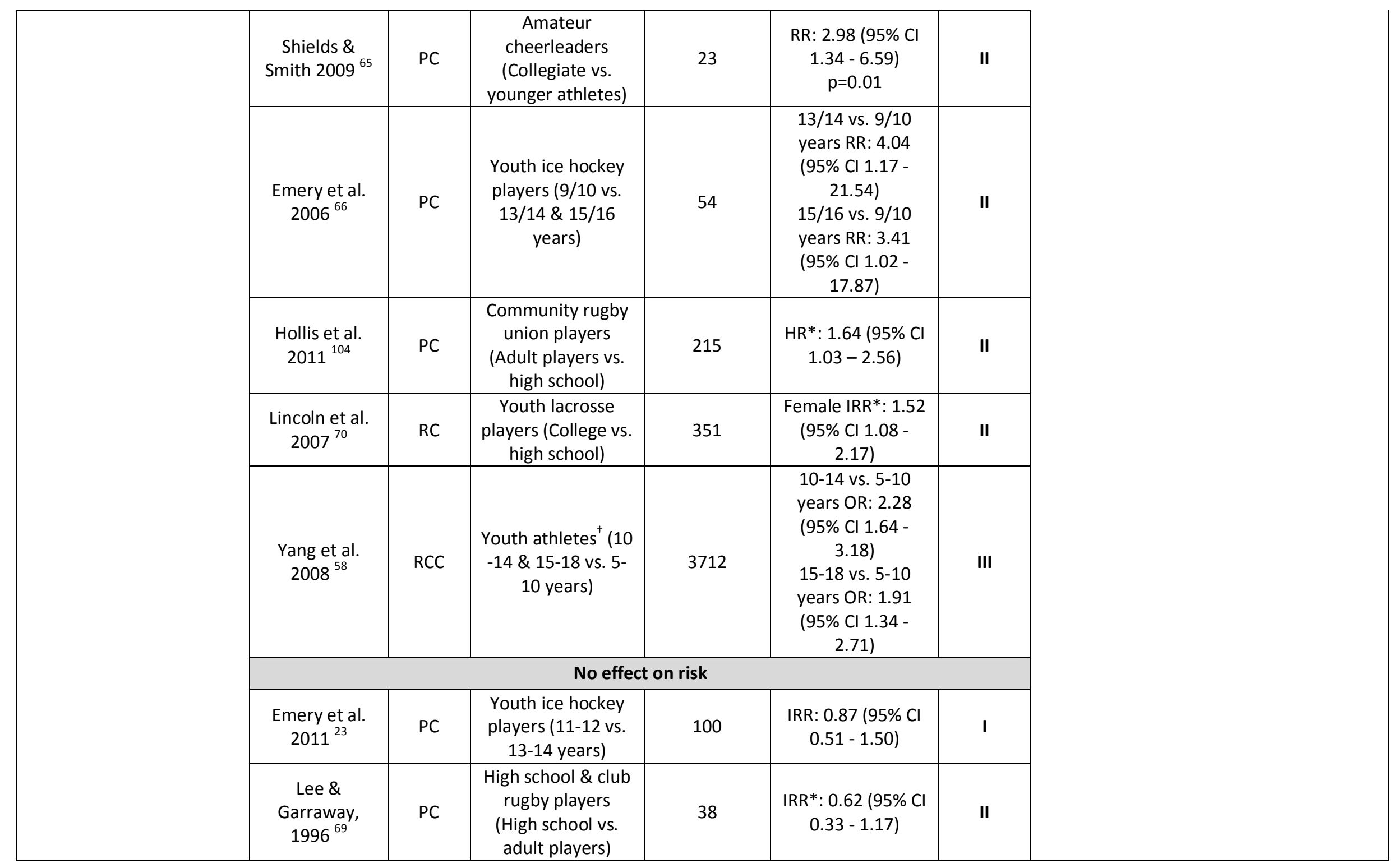




\begin{tabular}{|c|c|c|c|c|c|c|c|}
\hline & $\begin{array}{l}\text { Lincoln et al. } \\
2007^{70}\end{array}$ & $\mathrm{RC}$ & $\begin{array}{c}\text { Youth lacrosse } \\
\text { players (High } \\
\text { school vs. college } \\
\text { players) }\end{array}$ & 351 & $\begin{array}{l}\text { Male IRR*: } 0.76 \\
(95 \% \mathrm{Cl} 0.57- \\
1.01)\end{array}$ & II & \\
\hline \multirow{5}{*}{ 2.9 Genetics } & \multicolumn{6}{|c|}{ Increased risk } & \multirow[t]{5}{*}{ Lon } \\
\hline & $\begin{array}{c}\text { Terrell et al. } \\
2008^{92}\end{array}$ & $\mathrm{RC}$ & $\begin{array}{c}\text { Intercollegiate } \\
\text { soccer \& American } \\
\text { football players ( } \Pi \\
\text { APOE genotype \& } \\
\text { concussion history) }\end{array}$ & 90 & $\begin{array}{l}\text { OR: } 2.70(95 \% \mathrm{Cl} \\
1.1-6.8) p=0.03\end{array}$ & III & \\
\hline & \multicolumn{6}{|c|}{ No effect on risk } & \\
\hline & $\begin{array}{l}\text { Kristman et al. } \\
2008^{30}\end{array}$ & PC & $\begin{array}{c}\text { Collegiate } \\
\text { athletes }^{+}(A P O E \varepsilon 4 \\
\text { allele vs. } \\
\text { concussion history) }\end{array}$ & 28 & $\begin{array}{c}\text { Adjusted HR: } 1.06 \\
(95 \% \mathrm{Cl} 0.41- \\
2.72), \\
\text { RR: } 1.20(95 \% \mathrm{Cl} \\
0.5-2.6)\end{array}$ & II & \\
\hline & $\begin{array}{c}\text { Tierney et al. } \\
2010^{93}\end{array}$ & $\mathrm{RC}$ & $\begin{array}{l}\text { Collegiate female } \\
\text { soccer \& male } \\
\text { American football } \\
\text { players (rare APOE } \\
\text { allele vs. } \\
\text { concussion history, } \\
\text { minor APOE allele } \\
\text { carriers vs. } \\
\text { sustaining >two } \\
\text { concussions) } \\
\end{array}$ & 57 & $\begin{array}{c}\text { Rare } A P O E \text { allele } \\
\text { OR: } 9.80(95 \% \mathrm{Cl} \\
1.00-96.55) \\
\text { p=0.05, } \\
\text { Minor APOE allele } \\
\text { OR: } 8.40(95 \% \mathrm{Cl} \\
1.03-68.79) \\
p=0.04\end{array}$ & II & \\
\hline \multirow[t]{4}{*}{$\underline{2.10 \text { Behaviour }}$} & \multicolumn{6}{|c|}{ Increased risk } & \multirow[t]{4}{*}{ Lor } \\
\hline & $\begin{array}{l}\text { Gerberich et } \\
\text { al. } 1987^{86}\end{array}$ & $\mathrm{RC}$ & $\begin{array}{l}\text { High school ice } \\
\text { hockey players } \\
\text { (aggression \& } \\
\text { tension relief) }\end{array}$ & 249 & $\begin{array}{c}\text { OR: } 4.20(99 \% \mathrm{Cl} \\
1.68-10.32) \\
p<0.002\end{array}$ & II & \\
\hline & \multicolumn{6}{|c|}{ Decreased risk } & \\
\hline & $\begin{array}{l}\text { Koh et al. } \\
2004^{54}\end{array}$ & PC & $\begin{array}{l}\text { Youth taekwando } \\
\text { athletes (using } \\
\text { blocking skills) }\end{array}$ & 229 & $\begin{array}{c}\text { OR: } 0.57(95 \% \mathrm{Cl} \\
0.37-0.88) \\
p=0.01\end{array}$ & 1 & \\
\hline
\end{tabular}




\begin{tabular}{|c|c|c|c|c|c|c|c|}
\hline & \multicolumn{6}{|c|}{ No effect on risk } & \\
\hline & $\begin{array}{l}\text { Emery et al. } \\
2010^{21}\end{array}$ & PC & $\begin{array}{c}\text { Youth ice hockey } \\
\text { players } \\
\text { (preference to } \\
\text { body check) }\end{array}$ & 101 & $\begin{array}{c}\text { IRR: } 2.52(95 \% \mathrm{Cl} \\
1.00-6.35)\end{array}$ & 1 & \\
\hline & $\begin{array}{l}\text { Emery et al. } \\
2011^{23}\end{array}$ & PC & $\begin{array}{l}\text { Youth ice hockey } \\
\text { players (with body } \\
\text { checking } \\
\text { experience vs. no } \\
\text { experience) }\end{array}$ & 51 & $\begin{array}{c}\text { IRR: } 0.87(95 \% \mathrm{Cl} \\
0.51-1.50)\end{array}$ & II & \\
\hline \multicolumn{8}{|c|}{ Extrinsic Risk Factors } \\
\hline \multirow[t]{5}{*}{ 2.2 Match vs. practice } & \multicolumn{6}{|c|}{ Increased risk } & \multirow[t]{5}{*}{$\mathrm{High}$} \\
\hline & $\begin{array}{c}\text { Kemp et al. } \\
2008^{63}\end{array}$ & PC & $\begin{array}{c}\text { Male professional } \\
\text { rugby players }\end{array}$ & 101 & $\begin{array}{c}\mathrm{IRR}^{*}: 205(95 \% \mathrm{Cl} \\
83.4-503.8)\end{array}$ & 1 & \\
\hline & $\begin{array}{l}\text { Gessel et al. } \\
2007^{43}\end{array}$ & PC & Youth athletes $^{+}$ & 878 & $\begin{array}{c}\mathrm{IRR}^{*}: 4.80(95 \% \mathrm{Cl} \\
3.9-5.9)\end{array}$ & 1 & \\
\hline & $\begin{array}{l}\text { Nilsson et al. } \\
2013^{105}\end{array}$ & PC & $\begin{array}{l}\text { Male professional } \\
\text { soccer players }\end{array}$ & 48 & $\begin{array}{c}\text { RR: } 78.5 \text { (95\% Cl: } \\
24.4-252.5)\end{array}$ & 1 & \\
\hline & $\begin{array}{l}\text { Castile et al. } \\
2012^{46}\end{array}$ & $\mathrm{RC}$ & $\begin{array}{l}\text { High school } \\
\text { athletes }^{+}\end{array}$ & 2402 & $\begin{array}{c}\text { Football IRR*: } \\
8.13(95 \% \mathrm{Cl} 7.29 \\
-9.01) \\
\text { Boys soccer IRR*: } \\
11.68(95 \% \mathrm{Cl} 7.9- \\
17.3) \\
\text { Girls soccer IRR*: } \\
13.8(95 \% \mathrm{Cl} 9.6- \\
19.7) \\
\text { Volleyball IRR*: } \\
2.4(95 \% \mathrm{Cl} 1.4- \\
4.1) \\
\text { Boys basketball } \\
\text { IRR*: } 5.2(95 \% \mathrm{Cl} \\
3.5-7.8) \\
\text { Girls basketball } \\
\text { IRR*: } 7.8 \text { (95\% Cl }\end{array}$ & II & \\
\hline
\end{tabular}




\begin{tabular}{|c|c|c|c|c|c|}
\hline & & & & $\begin{array}{c}5.5-11) \\
\text { Wrestling IRR*: } \\
3.3(95 \% \mathrm{Cl} 2.4- \\
4.6) \\
\text { Baseball IRR*: } 5.5 \\
(95 \% \mathrm{Cl} 2.5-12.2) \\
\text { Softball IRR*: } 2 \\
(95 \% \mathrm{Cl} 1.2-3.2)\end{array}$ & \\
\hline $\begin{array}{l}\text { Kuzuhara et } \\
\text { al. } 2009^{106}\end{array}$ & PC & $\begin{array}{c}\text { Elite ice hockey } \\
\text { players }\end{array}$ & 5 & $\begin{array}{c}\text { IRR: } 16.00(95 \% \mathrm{Cl} \\
1.8-143.2)\end{array}$ & II \\
\hline $\begin{array}{l}\text { Agel et al. } \\
2007^{107}\end{array}$ & $\mathrm{RC}$ & $\begin{array}{l}\text { Female collegiate } \\
\text { ice hockey players }\end{array}$ & 77 & $\begin{array}{c}\text { IRR: } 8.20(95 \% \mathrm{Cl} \\
5.0-13.5)\end{array}$ & II \\
\hline $\begin{array}{l}\text { Agel et al. } \\
2007^{108}\end{array}$ & $\mathrm{RC}$ & $\begin{array}{l}\text { Female collegiate } \\
\text { basketball players }\end{array}$ & 240 & $\begin{array}{c}\text { IRR: } 3.30(95 \% \mathrm{Cl} \\
2.8-4.0)\end{array}$ & II \\
\hline $\begin{array}{l}\text { Dick et al. } \\
2007^{109}\end{array}$ & $\mathrm{RC}$ & $\begin{array}{c}\text { Female collegiate } \\
\text { field hockey } \\
\text { players }\end{array}$ & 129 & $\begin{array}{c}\text { IRR: } 6.10(95 \% \mathrm{Cl} \\
4.3-8.7)\end{array}$ & II \\
\hline $\begin{array}{l}\text { Dick, et al. } \\
2007^{110}\end{array}$ & $\mathrm{RC}$ & $\begin{array}{l}\text { Female collegiate } \\
\text { lacrosse players }\end{array}$ & 213 & $\begin{array}{c}\text { IRR: } 4.60(95 \% \mathrm{Cl} \\
3.5-6.0)\end{array}$ & II \\
\hline $\begin{array}{l}\text { Dick et al. } \\
2007^{111}\end{array}$ & $\mathrm{RC}$ & $\begin{array}{c}\text { Male collegiate } \\
\text { basketball players }\end{array}$ & 387 & $\begin{array}{c}\text { IRR: } 2.70(95 \% \mathrm{Cl} \\
2.6-2.8)\end{array}$ & II \\
\hline $\begin{array}{c}\text { Marar et al. } \\
2012^{112}\end{array}$ & $\mathrm{RC}$ & $\begin{array}{l}\text { Male \& female } \\
\text { high school } \\
\text { athletes }^{\dagger}\end{array}$ & 1936 & $\begin{array}{c}\text { Male football IRR: } \\
7.4(95 \% \mathrm{Cl} 6.5 \text { - } \\
8.4) \\
\text { Male ice hockey } \\
\text { IRR: } 13.2(95 \% \mathrm{Cl} \\
7.0-25.0) \\
\text { Male lacrosse IRR: } \\
9.5 \text { (95\% CI } 5.5- \\
15.5) \\
\text { Male soccer IRR: } \\
\text { 13.5 (95\% Cl } 7.8- \\
23.3) \\
\text { Male wrestling } \\
\text { IRR: } 3.6(95 \% \mathrm{Cl} \\
2.5-5.2)\end{array}$ & II \\
\hline
\end{tabular}




\begin{tabular}{|c|c|c|c|c|c|}
\hline & & & & $\begin{array}{c}\text { Male basketball } \\
\text { IRR: } 6.8(95 \% \mathrm{Cl} \\
4.3-10.7) \\
\text { Male baseball IRR: } \\
\text { 11.0 (95\% Cl 3.0- } \\
26.1) \\
\text { Female soccer } \\
\text { IRR: } 11.6 \text { (95\% Cl } \\
7.6-17.6) \\
\text { Female lacrosse } \\
\text { IRR: } 6.6 \text { (95\% Cl } \\
3.8-12.1) \\
\text { Female basketball } \\
\text { IRR: } 9.2(95 \% \mathrm{Cl} \\
5.5-14.1) \\
\text { Female field } \\
\text { hockey IRR: } 2.9 \\
\text { (95\% Cl } 1.7-5.1) \\
\text { Female softball } \\
\text { IRR: } 3.2(95 \% \mathrm{Cl} \\
1.9-5.4) \\
\text { Female volleyball } \\
\text { IRR: } 2.1 \text { (95\% Cl } \\
1.04-4.3)\end{array}$ & \\
\hline $\begin{array}{c}\text { Dick et al. } \\
2007^{34}\end{array}$ & $\mathrm{RC}$ & $\begin{array}{l}\text { Male collegiate } \\
\text { football players }\end{array}$ & 4404 & $\begin{array}{c}\text { IRR } 11.10(95 \% \mathrm{Cl} \\
10.5-11.8)\end{array}$ & II \\
\hline $\begin{array}{l}\text { Agel et al. } \\
2007^{113}\end{array}$ & $\mathrm{RC}$ & $\begin{array}{c}\text { Male collegiate } \\
\text { soccer players }\end{array}$ & 500 & $\begin{array}{c}\text { IRR: } 13.50(95 \% \mathrm{Cl} \\
10.9-16.6)\end{array}$ & II \\
\hline $\begin{array}{l}\text { Agel et al. } \\
2007^{114}\end{array}$ & $\mathrm{RC}$ & $\begin{array}{c}\text { Male collegiate ice } \\
\text { hockey players }\end{array}$ & 527 & $\begin{array}{c}\text { IRR: } 14.70(95 \% \mathrm{Cl} \\
11.9-18.2) \\
\end{array}$ & II \\
\hline $\begin{array}{l}\text { Dick et al. } \\
2007^{115}\end{array}$ & $\mathrm{RC}$ & $\begin{array}{l}\text { Male collegiate } \\
\text { lacrosse players }\end{array}$ & 271 & $\begin{array}{c}\text { IRR: } 9.00(95 \% \mathrm{Cl} \\
7.1-11.5) \\
\end{array}$ & II \\
\hline $\begin{array}{l}\text { Dick et al. } \\
2007^{116}\end{array}$ & $\mathrm{RC}$ & $\begin{array}{c}\text { Female collegiate } \\
\text { soccer players }\end{array}$ & 593 & $\begin{array}{c}\text { IRR: } 11.80(95 \% \mathrm{Cl} \\
11.4-12.3)\end{array}$ & II \\
\hline
\end{tabular}




\begin{tabular}{|c|c|c|c|c|c|}
\hline $\begin{array}{l}\text { Marshall et al. } \\
\qquad 2007^{117}\end{array}$ & $\mathrm{RC}$ & $\begin{array}{l}\text { Female collegiate } \\
\text { softball players }\end{array}$ & 228 & $\begin{array}{c}\text { IRR: } 3.60(95 \% \mathrm{Cl} \\
3.4-3.8)\end{array}$ & II \\
\hline $\begin{array}{c}\text { Booher et al. } \\
2003^{118}\end{array}$ & PC & $\begin{array}{l}\text { Male collegiate } \\
\text { football players }\end{array}$ & 373 & $\begin{array}{c}\text { IRR*: } 22.20(95 \% \\
\text { Cl } 17.9-27.7)\end{array}$ & II \\
\hline $\begin{array}{l}\text { Goodman et } \\
\text { al. } 2001^{119}\end{array}$ & $\begin{array}{c}\text { PC \& } \\
\text { RC }\end{array}$ & $\begin{array}{c}\text { Male amateur ice } \\
\text { hockey players }\end{array}$ & 379 & $\begin{array}{c}\text { IRR*: } 9.90(95 \% \mathrm{Cl} \\
2.35-41.7)\end{array}$ & II \\
\hline $\begin{array}{l}\text { Marshall et al. } \\
2001^{120}\end{array}$ & PC & $\begin{array}{c}\text { Male high school } \\
\text { rugby players }\end{array}$ & 17 & $\begin{array}{c}\text { IRR*: } 7.40(95 \% \mathrm{Cl} \\
2.6-21.0)\end{array}$ & II \\
\hline $\begin{array}{l}\text { Dick et al. } \\
2007^{121}\end{array}$ & $\mathrm{RC}$ & $\begin{array}{l}\text { Male collegiate } \\
\text { baseball players }\end{array}$ & 210 & $\begin{array}{c}\mathrm{IRR}^{*}: 6.30(95 \% \mathrm{Cl} \\
4.7-8.5)\end{array}$ & II \\
\hline $\begin{array}{l}\text { Agel et al. } \\
2007^{122}\end{array}$ & $\mathrm{RC}$ & $\begin{array}{l}\text { Female collegiate } \\
\text { volleyball players }\end{array}$ & 141 & $\begin{array}{c}\mathrm{IR}^{*}: 2.50(95 \% \mathrm{Cl} \\
1.8-3.5)\end{array}$ & II \\
\hline $\begin{array}{l}\text { Marshall et al. } \\
2007^{123}\end{array}$ & $\mathrm{RC}$ & $\begin{array}{l}\text { Female collegiate } \\
\text { gymnasts }\end{array}$ & 64 & $\begin{array}{c}\mathrm{IRR}^{*}: 2.80(95 \% \mathrm{Cl} \\
1.6-5.3)\end{array}$ & II \\
\hline $\begin{array}{l}\text { Kerr et al. } \\
2008^{57}\end{array}$ & PC & $\begin{array}{l}\text { Male \& female } \\
\text { rugby players }\end{array}$ & 81 & $\begin{array}{l}\text { Male IRR*: } 5.80 \\
(95 \% \text { Cl } 2.8-12) \\
\text { Female IRR*: } 5.3 \\
(95 \% \mathrm{Cl} 2.3-12.1)\end{array}$ & II \\
\hline $\begin{array}{c}\text { Gabett et al. } \\
2004\end{array}$ & PC & $\begin{array}{l}\text { Rugby league } \\
\text { players }\end{array}$ & 37 & $\begin{array}{c}\mathrm{IRR}^{*}: 166(95 \% \mathrm{Cl} \\
15.9-846)\end{array}$ & II \\
\hline $\begin{array}{c}\text { Kristman et al. } \\
2008^{30}\end{array}$ & PC & $\begin{array}{l}\text { Collegiate } \\
\text { athletes }^{+}\end{array}$ & 28 & $\begin{array}{c}\text { RR: } 4.10(95 \% \mathrm{Cl} \\
1.9-8.8)\end{array}$ & II \\
\hline $\begin{array}{l}\text { Guskiewicz et } \\
\text { al. } 2003^{29}\end{array}$ & PC & $\begin{array}{c}\text { Collegiate } \\
\text { American football } \\
\text { players }\end{array}$ & 196 & $\begin{array}{c}\mathrm{IRR}^{*}: 8.10(95 \% \mathrm{Cl} \\
\quad 6.13-10.7)\end{array}$ & II \\
\hline $\begin{array}{l}\text { Covassin et al. } \\
2003^{125}\end{array}$ & $\mathrm{RC}$ & $\begin{array}{l}\text { Collegiate } \\
\text { athletes }^{+}\end{array}$ & 1278 & $\begin{array}{c}\text { Male hockey IRR*: } \\
\text { 13.5 (95\% Cl } 8.83 \\
-10.67), \\
\text { Male soccer IRR*: } \\
18.86 \text { (95\% Cl } \\
11.89-29.9), \\
\text { Male football: } \\
\text { IRR*: } 10.9 \text { (95\% Cl } \\
\text { 9.71 - 12.25), } \\
\text { Male lacrosse } \\
\text { IRR*: } 10.33 \text { (95\% }\end{array}$ & II \\
\hline
\end{tabular}




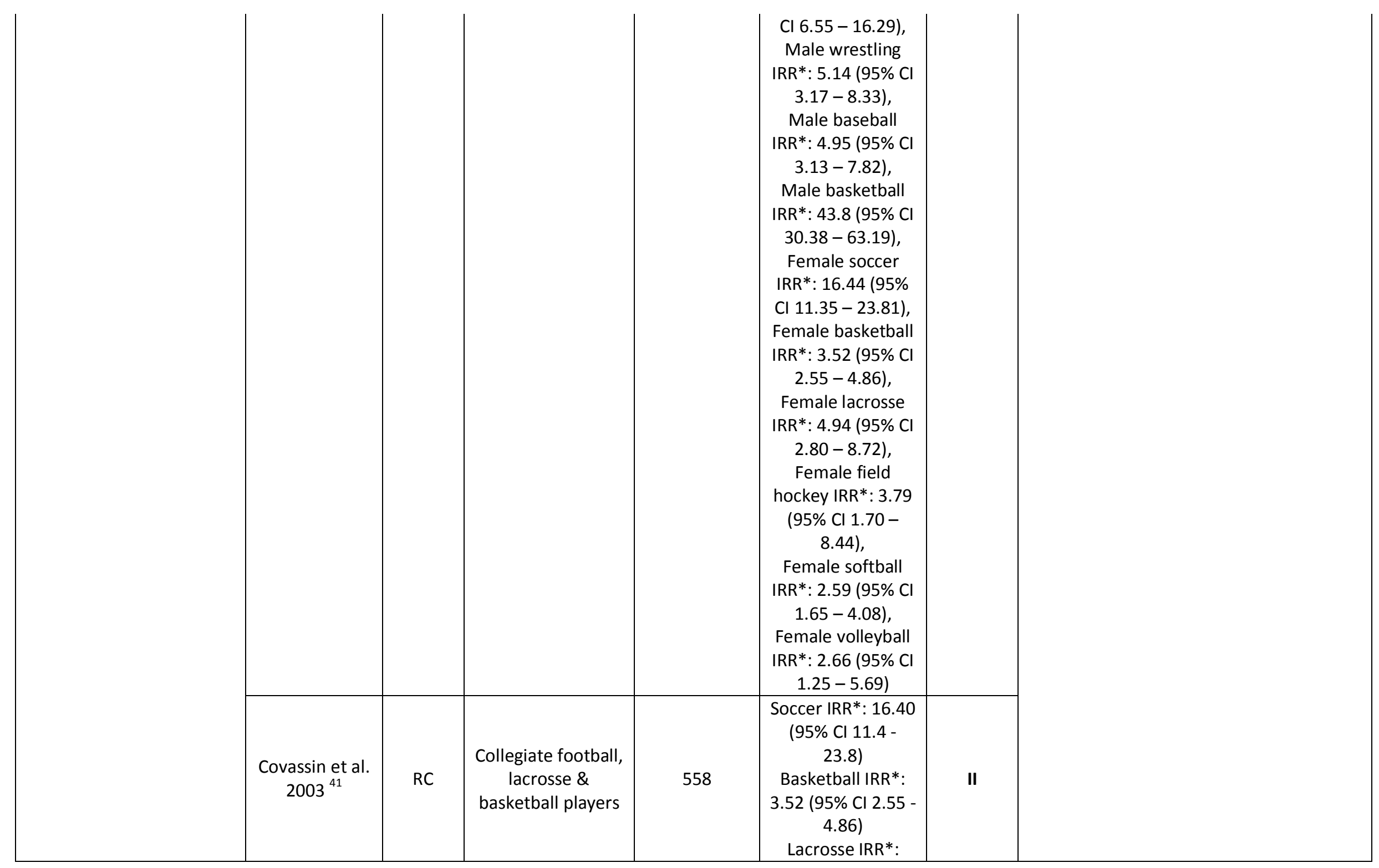




\begin{tabular}{|c|c|c|c|c|c|c|c|}
\hline & & & & & $\begin{array}{c}4.94(95 \% \mathrm{Cl} 2.8- \\
8.7) \\
\text { Softball IRR*: } 2.61 \\
(95 \% \mathrm{Cl} 1.66- \\
4.11) \\
\text { Gymnastics IRR*: } \\
1.02(95 \% \mathrm{Cl} 0.12- \\
8.7)\end{array}$ & & \\
\hline \multirow[t]{3}{*}{ 2.13 Match period } & \multicolumn{6}{|c|}{ No effect on risk } & \multirow[t]{3}{*}{ Low } \\
\hline & $\begin{array}{c}\text { Tegner \& } \\
\text { Lorentzon, } \\
1996^{103}\end{array}$ & $\begin{array}{l}\mathrm{PC} \& \\
\mathrm{RC}\end{array}$ & $\begin{array}{l}\text { Elite ice hockey } \\
\text { players ( } 2 \text { nd vs. } \\
\text { 3rd period) }\end{array}$ & 94 & $\begin{array}{c}x^{2}: 9.71, d f=2 \\
p<0.01\end{array}$ & II & \\
\hline & $\begin{array}{l}\text { Hinton-Bayre } \\
\text { et al. } 2004^{64}\end{array}$ & PC & $\begin{array}{l}\text { Professional rugby } \\
\text { league players (1st } \\
\text { vs. } 2 \text { nd half) }\end{array}$ & 43 & $\begin{array}{c}\text { IRR: } 1.26(95 \% \mathrm{Cl} \\
0.66-2.44)\end{array}$ & II & \\
\hline \multirow[t]{3}{*}{ 2.11 Mechanism of injury } & \multicolumn{6}{|c|}{ No effect on risk } & \multirow[t]{3}{*}{ Low } \\
\hline & $\begin{array}{l}\text { Darling et al. } \\
\quad 2011^{97}\end{array}$ & PC & $\begin{array}{c}\text { Youth hockey } \\
\text { players } \\
\text { (unintentional vs. } \\
\text { intentional } \\
\text { collisions) }\end{array}$ & 29 & $p=0.04$ & II & \\
\hline & $\begin{array}{c}\text { Delaney et al. } \\
2006^{98}\end{array}$ & PC & $\begin{array}{l}\text { Collegiate soccer, } \\
\text { ice hockey \& } \\
\text { American football } \\
\text { players (hit on } \\
\text { head or helmet) }\end{array}$ & 69 & $\begin{array}{c}\text { Soccer: } p<0.0001, \\
\text { Football: } \\
p<0.0001 \\
\text { Ice hockey: } \\
p=0.0067\end{array}$ & II & \\
\hline \multirow[t]{3}{*}{ 2.4 Playing position } & \multicolumn{6}{|c|}{ Increased risk } & \multirow[t]{3}{*}{ Low } \\
\hline & $\begin{array}{l}\text { Pellman et al. } \\
2004\end{array}$ & PC & $\begin{array}{l}\text { Elite American } \\
\text { football players } \\
\text { (quarterbacks vs. } \\
\text { all other positions) }\end{array}$ & 787 & $\begin{array}{c}\text { IRR*: } 1.72(95 \% \mathrm{Cl} \\
1.14-2.60) \text { to } 54 \\
(95 \% \mathrm{Cl} 7.49- \\
389.45)\end{array}$ & II & \\
\hline & \multicolumn{6}{|c|}{ Decreased risk } & \\
\hline
\end{tabular}




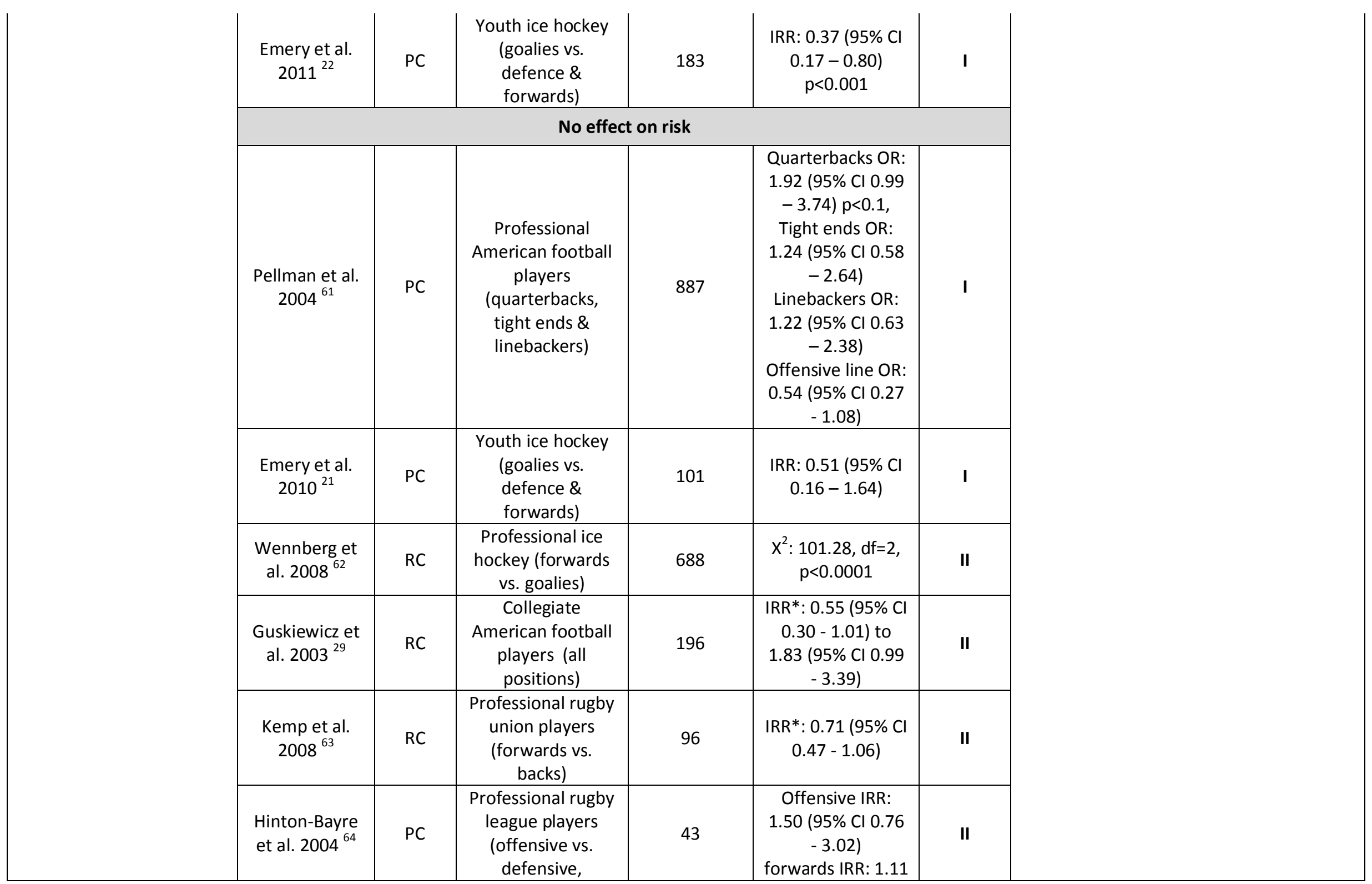




\begin{tabular}{|c|c|c|c|c|c|c|c|}
\hline & & & forwards vs. backs) & & $\begin{array}{l}(95 \% \mathrm{Cl} 0.58 \text { - } \\
2.12)\end{array}$ & & \\
\hline \multirow[t]{7}{*}{ 2.7 Playing level } & \multicolumn{6}{|c|}{ Lower playing level associated with increased risk } & \multirow[t]{7}{*}{ Lo } \\
\hline & $\begin{array}{l}\text { Guskiewicz et } \\
\text { al. } 2000^{68}\end{array}$ & PC & $\begin{array}{l}\text { High school \& } \\
\text { collegiate } \\
\text { American football } \\
\text { players (College } \\
\text { division I,III, III) }\end{array}$ & 1003 & $\begin{array}{c}\text { Division I vs. } \\
\text { division II IRR*: } \\
1.41 \text { (95\% CI 1.15 } \\
-1.72) \\
\text { Division I vs. } \\
\text { division III IRR*: } \\
1.39 \text { (95\% Cl } 1.15 \\
-1.67) \\
\text { Division I vs. } \\
\text { division III } \chi^{2}: \\
12.16, \mathrm{df}=3 \\
\text { p }<0.05\end{array}$ & 1 & \\
\hline & $\begin{array}{l}\text { Guskiewicz et } \\
\text { al. } 2003^{29}\end{array}$ & PC & $\begin{array}{c}\text { Collegiate } \\
\text { American football } \\
\text { players (College } \\
\text { division I,II, III) }\end{array}$ & 196 & $\begin{array}{c}\text { Division I vs. } \\
\text { division III IRR*: } \\
2.13 \text { (95\% Cl } 1.47 \\
-3.03) \\
\text { Division II vs. } \\
\text { division III IRR*: } \\
2.13(95 \% \mathrm{Cl} 1.28 \\
-3.45) \\
\end{array}$ & II & \\
\hline & \multicolumn{6}{|c|}{ No effect on risk } & \\
\hline & $\begin{array}{l}\text { Emery et al. } \\
2010^{21}\end{array}$ & PC & $\begin{array}{l}\text { Youth ice hockey } \\
\text { players (top 20\% } \\
\text { vs. mid 40\%) }\end{array}$ & 101 & $\begin{array}{c}\text { IRR: } 1.28(95 \% \mathrm{Cl} \\
0.75-2.17)\end{array}$ & I & \\
\hline & $\begin{array}{l}\text { Emery et al. } \\
2011^{22}\end{array}$ & PC & $\begin{array}{l}\text { Youth ice hockey } \\
\text { players (top 10\% } \\
\text { vs. next 20\%) }\end{array}$ & 183 & $\begin{array}{c}\text { IRR: } 0.97(95 \% \mathrm{Cl} \\
0.66-1.43) \\
p>0.05\end{array}$ & I & \\
\hline & $\begin{array}{l}\text { Stephneson et } \\
\text { al. } 1996^{87}\end{array}$ & PC & $\begin{array}{l}\text { Rugby league } \\
\text { players (1st team } \\
\text { vs. A-team) }\end{array}$ & 35 & $\begin{array}{c}\text { IRR*: } 0.89(95 \% \mathrm{Cl} \\
0.46-1.7)\end{array}$ & II & \\
\hline
\end{tabular}




\begin{tabular}{|c|c|c|c|c|c|c|c|}
\hline & $\begin{array}{l}\text { Hinton-Bayre } \\
\text { et al. } 2004^{64}\end{array}$ & PC & $\begin{array}{c}\text { Professional rugby } \\
\text { league players } \\
\text { (First team vs. age } \\
\text { group) }\end{array}$ & 43 & $\begin{array}{c}\text { IRR: } 1.67(95 \% \mathrm{Cl} \\
0.68-4.32)\end{array}$ & II & \\
\hline \multirow[t]{9}{*}{ 2.6 Protective equipment } & \multicolumn{6}{|c|}{ Increased risk } & \multirow[t]{9}{*}{ Lo } \\
\hline & $\begin{array}{c}\text { Gerberich, } \\
1987^{86}\end{array}$ & $\mathrm{RC}$ & $\begin{array}{c}\text { High school ice } \\
\text { hockey players } \\
\text { (perceived face } \\
\text { mask blocked } \\
\text { vision vs. no } \\
\text { perception) }\end{array}$ & 23 & $\begin{array}{c}\text { OR: } 5.15(95 \% \mathrm{Cl} \\
2.25-11.81) \\
p<0.001\end{array}$ & II & \\
\hline & \multicolumn{6}{|c|}{ Decreased risk } & \\
\hline & $\begin{array}{l}\text { Kemp et al. } \\
2008^{63}\end{array}$ & PC & $\begin{array}{l}\text { Male professional } \\
\text { rugby union } \\
\text { players (headgear } \\
\text { vs. no headgear) }\end{array}$ & 81 & $\begin{array}{c}\text { IRR*: } 0.43(95 \% \mathrm{Cl} \\
0.2-0.94)\end{array}$ & 1 & \\
\hline & $\begin{array}{l}\text { Hollis et al. } \\
2009^{25}\end{array}$ & PC & $\begin{array}{c}\text { Amateur rugby } \\
\text { union players } \\
\text { (headgear vs. no } \\
\text { headgear) }\end{array}$ & 347 & $\begin{array}{c}\text { IRR: } 0.57(95 \% \mathrm{Cl} \\
0.40-0.82) \\
p<0.01\end{array}$ & II & \\
\hline & $\begin{array}{l}\text { Singh et al. } \\
2009^{76}\end{array}$ & $\mathrm{RC}$ & $\begin{array}{c}\text { High school } \\
\text { American football } \\
\text { players (mouth } \\
\text { guard users vs. } \\
\text { non-users) }\end{array}$ & 26 & $\begin{array}{c}\text { OR: } 0.03(95 \% \mathrm{Cl} \\
0.01-0.12) \mathrm{p}< \\
0.05\end{array}$ & II & \\
\hline & \multicolumn{6}{|c|}{ No effect on risk } & \\
\hline & $\begin{array}{l}\text { Wisniewski et } \\
\text { al. } 2004^{77}\end{array}$ & PC & $\begin{array}{l}\text { American football } \\
\text { players (custom- } \\
\text { made vs. non } \\
\text { custom-made } \\
\text { mouth guards) }\end{array}$ & 369 & $\begin{array}{c}\text { RR: } 1.32(95 \% \mathrm{Cl} \\
0.99-1.75)\end{array}$ & I & \\
\hline & $\begin{array}{l}\text { Mclntosh et } \\
\text { al. } 2009^{83}\end{array}$ & $\mathrm{RCT}$ & $\begin{array}{l}\text { Youth rugby union } \\
\text { players (headgear } \\
\text { vs. no headgear) }\end{array}$ & 199 & $\begin{array}{c}\text { Modified } \\
\text { headgear IRR: } \\
1.13(95 \% \mathrm{Cl} 0.67 \\
-1.90) p=0.65\end{array}$ & I & \\
\hline
\end{tabular}




\begin{tabular}{|c|c|c|c|c|c|}
\hline & & & & $\begin{array}{c}\text { Standard } \\
\text { headgear IRR: } \\
0.95 \text { (95\% Cl } 0.54 \\
-1.69) \text { p }=0.87\end{array}$ & \\
\hline $\begin{array}{l}\text { Kemp et al. } \\
2008^{63}\end{array}$ & PC & $\begin{array}{l}\text { Male professional } \\
\text { rugby union } \\
\text { players (mouth } \\
\text { guards vs. no } \\
\text { mouth guards) }\end{array}$ & 81 & $\begin{array}{c}\text { IRR*: } 0.69(95 \% \mathrm{Cl} \\
0.41-1.17)\end{array}$ & I \\
\hline $\begin{array}{c}\text { Delaney et al. } \\
2008^{40}\end{array}$ & $\mathrm{RC}$ & $\begin{array}{l}\text { Youth soccer } \\
\text { players (no } \\
\text { headgear vs. } \\
\text { headgear) }\end{array}$ & 133 & $\begin{array}{l}\text { Adjusted RR: } 2.65 \\
\quad(p<0.0001)\end{array}$ & II \\
\hline $\begin{array}{c}\text { Benson et al. } \\
1999^{84}\end{array}$ & PC & $\begin{array}{c}\text { Collegiate hockey } \\
\text { players (half vs. full } \\
\text { visor shields) }\end{array}$ & 79 & $\begin{array}{c}\text { RR: } 0.97(95 \% \mathrm{Cl} \\
0.61-1.54) \\
p=0.90\end{array}$ & II \\
\hline $\begin{array}{c}\text { Marshall et al. } \\
2005^{72}\end{array}$ & PC & $\begin{array}{l}\text { Rugby union } \\
\text { players } \\
\text { (Headgear/mouth } \\
\text { guard users vs. } \\
\text { non-users) }\end{array}$ & 22 & $\begin{array}{c}\text { Headgear } \\
\text { adjusted IRR: } 1.13 \\
(95 \% \mathrm{Cl}: 0.40- \\
3.16) \\
\text { Mouth guard } \\
\text { adjusted IRR: } 1.62 \\
(95 \% \mathrm{Cl}: 0.51 \text { - } \\
5.11) \\
\end{array}$ & II \\
\hline $\begin{array}{l}\text { Stuart et al. } \\
2002^{85}\end{array}$ & PC & $\begin{array}{l}\text { Elite \& amateur ice } \\
\text { hockey players } \\
\text { (full vs. half vs. no } \\
\text { facial protection) }\end{array}$ & 11 & $\begin{array}{c}\text { Full vs. none IRR*: } \\
0.24 \text { ( } 95 \% \mathrm{Cl} 0.04 \\
-1.3) \\
\text { Full vs. partial } \\
\text { IRR*: } 0.35(95 \% \mathrm{Cl} \\
0.07-1.82) \\
\text { Partial vs. none } \\
\text { IRR*: } 0.67(95 \% \mathrm{Cl} \\
0.18-2.5)\end{array}$ & II \\
\hline $\begin{array}{l}\text { Labella et al. } \\
2002^{71}\end{array}$ & PC & $\begin{array}{c}\text { Collegiate } \\
\text { basketball players } \\
\text { (mouth guard }\end{array}$ & 37 & $\begin{array}{c}\text { IRR*: } 0.64(95 \% \mathrm{Cl} \\
0.2-2.1)\end{array}$ & II \\
\hline
\end{tabular}




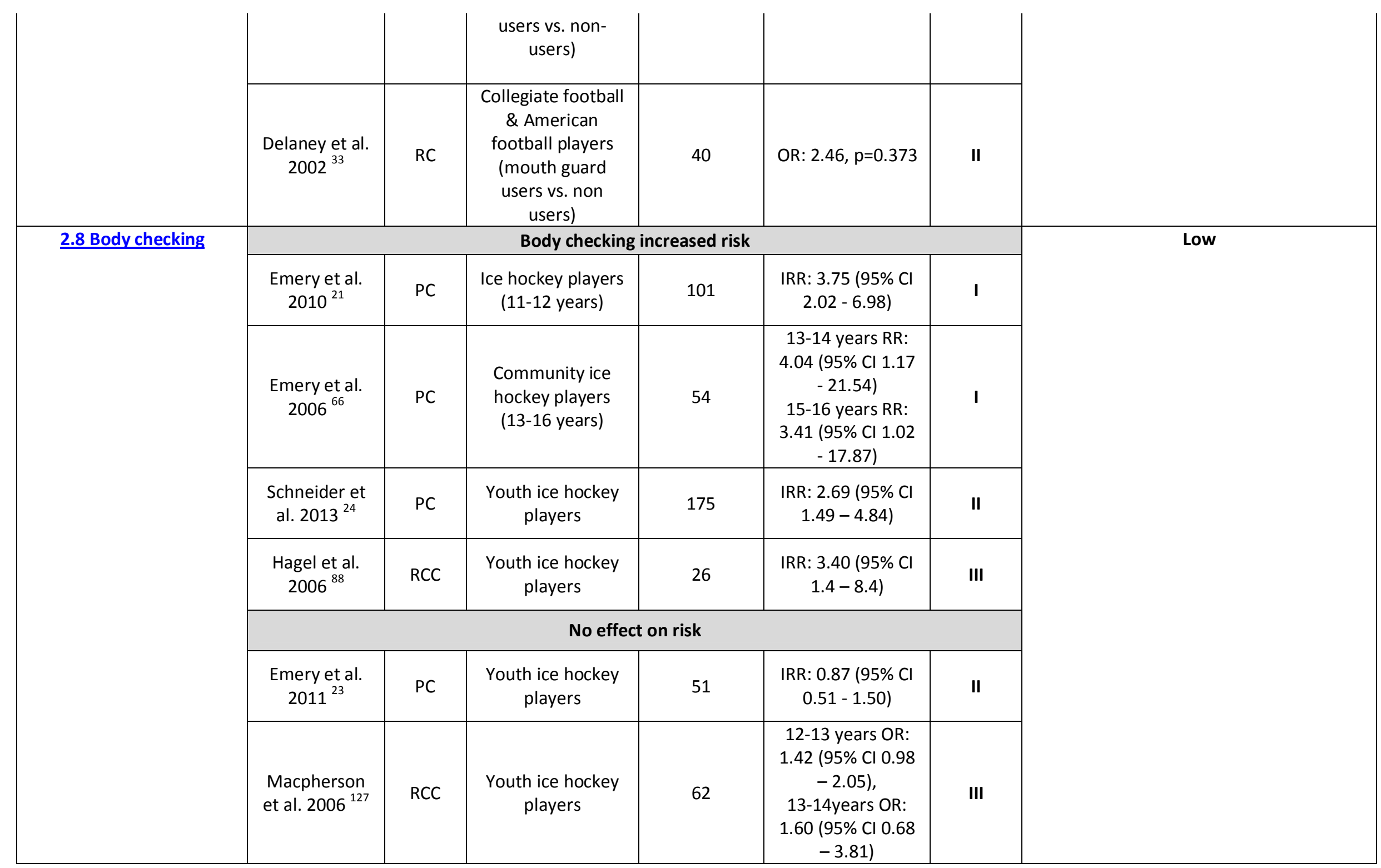




\begin{tabular}{|c|c|c|c|c|c|c|c|}
\hline \multirow[t]{5}{*}{ 2.12 Environment } & \multicolumn{6}{|c|}{ Increased risk } & \multirow[t]{5}{*}{ Low } \\
\hline & $\begin{array}{l}\text { Nation et al. } \\
2011^{36}\end{array}$ & $\mathrm{RC}$ & $\begin{array}{l}\text { American football } \\
\text { players (school vs. } \\
\text { other locations) }\end{array}$ & 4469 & $\begin{array}{c}\text { OR: } 1.41(95 \% \mathrm{Cl} \\
1.24-1.61)\end{array}$ & II & \\
\hline & \multicolumn{6}{|c|}{ No effect on risk } & \\
\hline & $\begin{array}{l}\text { Bjørneboe et } \\
\text { al. } 2010^{101}\end{array}$ & PC & $\begin{array}{l}\text { Professional soccer } \\
\text { players (grass vs. } \\
\text { artificial turf) }\end{array}$ & 54 & $\begin{array}{c}\text { IRR: } 0.46(95 \% \mathrm{Cl} \\
0.18-1.16)\end{array}$ & II & \\
\hline & $\begin{array}{l}\text { Ekstrand et al. } \\
2011\end{array}$ & PC & $\begin{array}{c}\text { Elite soccer players } \\
\text { (grass vs. artificial } \\
\text { turf) }\end{array}$ & 37 & $\begin{array}{c}\text { Men RR: } 0.71 \\
(95 \% \mathrm{Cl} 0.29- \\
\text { 1.74) p>0.05, } \\
\text { Women RR: } 0.90 \\
\text { (95\% Cl } 0.20- \\
\text { 4.02) p >0.05 }\end{array}$ & II & \\
\hline \multicolumn{8}{|c|}{ 2.14 Other } \\
\hline \multirow[t]{3}{*}{ Anthropometry } & \multicolumn{6}{|c|}{ Increased risk } & \multirow[t]{3}{*}{ Low } \\
\hline & $\begin{array}{l}\text { Hollis et al. } \\
2011^{104}\end{array}$ & PC & $\begin{array}{c}\text { Community rugby } \\
\text { union players (low } \\
\text { BMI) }\end{array}$ & 215 & $\begin{array}{l}\text { BMI HR: } 1.77 \\
(95 \% \mathrm{Cl} 1.30- \\
2.42) \\
\end{array}$ & II & \\
\hline & $\begin{array}{l}\text { Schneider et } \\
\text { al. } 2013^{24}\end{array}$ & PC & $\begin{array}{c}\text { Youth ice hockey } \\
\text { players }\end{array}$ & 175 & $\begin{array}{c}\text { Lower } 25 \% \text { weight } \\
\text { IRR*: } 1.45(95 \% \mathrm{Cl} \\
1.05-2.00)\end{array}$ & II & \\
\hline Preseason Symptoms & $\begin{array}{l}\text { Schneider et } \\
\text { al. } 2013^{24}\end{array}$ & PC & $\begin{array}{c}\text { Youth ice hockey } \\
\text { players }\end{array}$ & 175 & $\begin{array}{c}\text { Headache IRR: } \\
1.47 \text { (95\% CI } 1.01 \\
-2.13) \\
\text { Neck pain IRR: } \\
1.67(95 \% \mathrm{Cl} 1.15 \\
-2.41) \\
\text { Dizziness IRR: } 3.11 \\
(95 \% \mathrm{Cl} 1.33- \\
7.26)\end{array}$ & II & Low \\
\hline Exposure & $\begin{array}{l}\text { Schneider et } \\
\text { al. } 2013^{24}\end{array}$ & PC & $\begin{array}{c}\text { Youth ice hockey } \\
\text { players }\end{array}$ & 175 & $\begin{array}{c}2 \text { year exposure } \\
\text { IRR: } 1.37(95 \% \mathrm{Cl} \\
1.02-1.86)\end{array}$ & II & Low \\
\hline
\end{tabular}




\begin{tabular}{|c|c|c|c|c|c|c|c|}
\hline Fitness & $\begin{array}{l}\text { Hollis et al. } \\
2011^{104}\end{array}$ & PC & $\begin{array}{c}\text { Community rugby } \\
\text { union players (less } \\
\text { training) }\end{array}$ & 215 & $\begin{array}{c}\text { Training HR: } 1.48 \\
\text { (95\% Cl } 1.06- \\
2.08)\end{array}$ & II & Low \\
\hline \multirow[t]{2}{*}{ Weather season } & \multicolumn{6}{|c|}{ Decreased risk } & \multirow[b]{2}{*}{ Low } \\
\hline & $\begin{array}{l}\text { Dick et al. } \\
2007^{34}\end{array}$ & $\mathrm{RC}$ & $\begin{array}{l}\text { Male collegiate } \\
\text { football players } \\
\text { (Spring practice } \\
\text { rule change) }\end{array}$ & 4404 & $\begin{array}{c}\text { IRR: } 0.57(95 \% \mathrm{Cl} \\
0.48-0.67)\end{array}$ & II & \\
\hline \multirow[t]{2}{*}{ Performance } & \multicolumn{6}{|c|}{ No effect on risk } & \multirow[t]{2}{*}{ Low } \\
\hline & $\begin{array}{l}\text { Emery et al. } \\
2011^{22}\end{array}$ & PC & $\begin{array}{l}\text { Youth ice hockey } \\
\text { players (greater } \\
\text { win-loss record) }\end{array}$ & 183 & $\begin{array}{c}\text { Win-loss record } \\
\text { IRR: } 0.70(95 \% \mathrm{Cl} \\
0.49-1.01) \\
\text { p>0.05 } \\
\text { Penalty minutes } \\
\text { IRR: } 1.07(95 \% \mathrm{Cl} \\
0.71-1.61) \\
\end{array}$ & $\mathbf{I}$ & \\
\hline Fitness & $\begin{array}{c}\text { Kontos et al. } \\
2005^{28}\end{array}$ & PC & $\begin{array}{c}\text { High school } \\
\text { American football } \\
\text { players (low } \\
\text { aerobic fitness vs. } \\
\text { higher aerobic } \\
\text { fitness) } \\
\end{array}$ & 23 & $\begin{array}{c}\text { OR: } 1.80(95 \% \mathrm{Cl} \\
0.68-4.80)\end{array}$ & II & Low \\
\hline Disability & $\begin{array}{c}\text { Wessels et al. } \\
2012^{45}\end{array}$ & $\mathrm{RC}$ & $\begin{array}{c}\text { Wheelchair } \\
\text { basketball players } \\
\text { (wheelchair users } \\
\text { vs. non-users) }\end{array}$ & 102 & OR: $0.54(p=0.05)$ & II & Low \\
\hline Injury Location & $\begin{array}{c}\text { Delaney et al. } \\
2006^{98}\end{array}$ & PC & $\begin{array}{c}\text { Collegiate } \\
\text { American football, } \\
\text { ice hockey \& } \\
\text { football players } \\
\text { (side/temporal } \\
\text { area of the } \\
\text { head/helmet) }\end{array}$ & 69 & $\begin{array}{c}\text { Football: } \\
p=0.0001 \\
\text { Soccer: } p=0.0032\end{array}$ & II & Low \\
\hline
\end{tabular}




\begin{tabular}{|c|c|c|c|c|c|c|}
\hline Weather season & $\begin{array}{c}\text { Gissane et al. } \\
2003 \text { 128 }\end{array}$ & CC & $\begin{array}{c}\text { Professional rugby } \\
\text { players (summer } \\
\text { vs. winter season } \\
\text { injuries) }\end{array}$ & IRR: $1.2, \mathrm{p}=0.7$ & III \\
\hline
\end{tabular}

${ }^{\dagger}$ populations from various sports were investigated

*recalculated IRR or inverted the original study's risk estimate and confidence interval by two of the authors (SA and SM)

PCS - prospective case series, PC - prospective cohort, RCC - retrospective case control, RC - retrospective cohort

APOE - apolipoprotein E, IRR - incidence rate ratio, RR - relative risk, OR - odds ratio, HR - hazard ratio, yr - year, $\mathrm{X}^{2}$ - chi square statistical analysis, df - degrees of freedom 
Table 3: Summary of the level of certainty of concussion risk factors

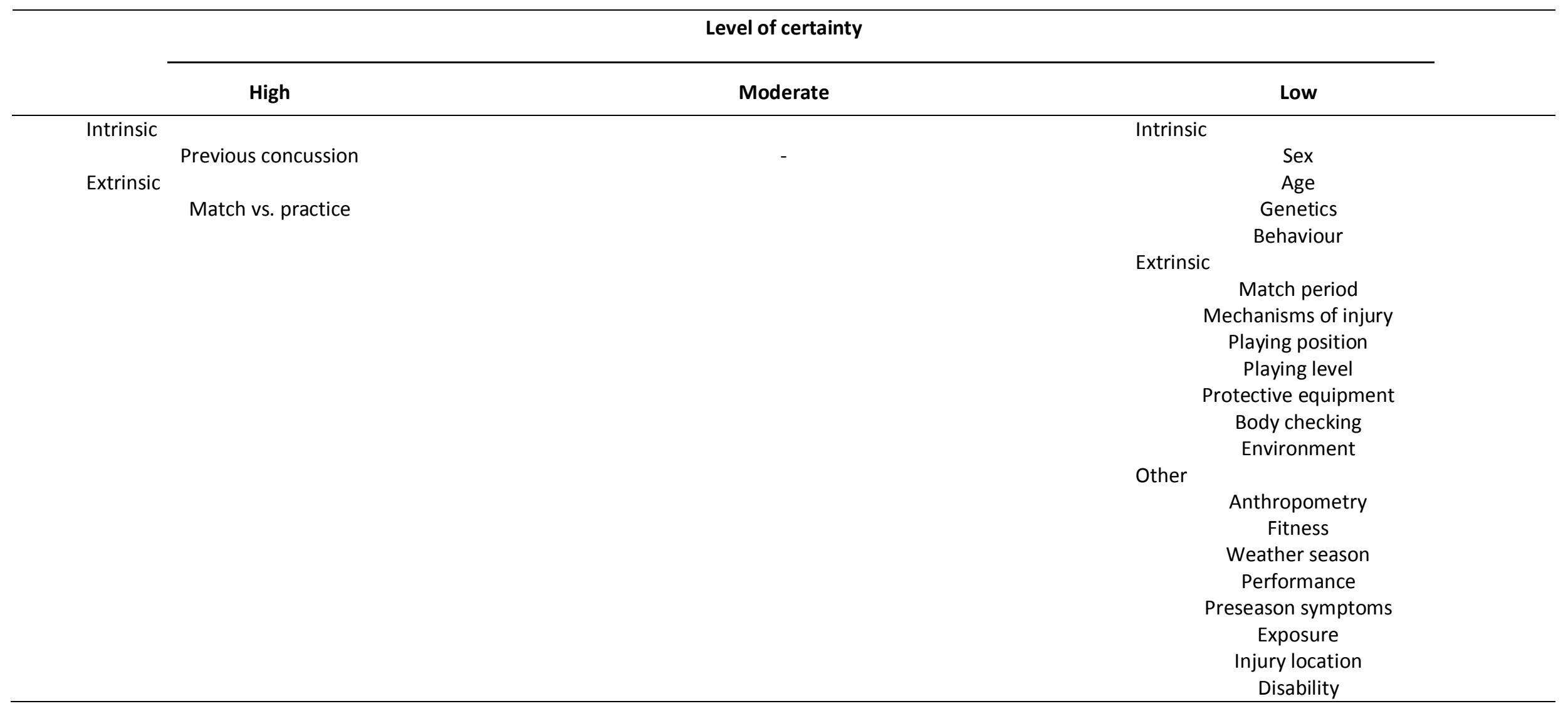




\section{Limitations}

There were several limitations to this systematic review. Studies which did not differentiate between concussions and other types of mild traumatic brain injury or only included concussions where there was loss of consciousness were excluded from our analysis. A systematic review of concussion incidence in different sports has previously been published $^{129}$ therefore sport type, as a risk factor, was excluded from the current review. Although biomechanical models are important research tools, most of the biomechanical studies used simulation models or mainly investigated head impacts and not specifically concussion. Consequently, these studies were excluded from this systematic review.

\section{Future Research}

The investigation of risk factors is an important step toward understanding the aetiology of concussion. Although several risk factors were identified in the appraised studies, poor study methodology compromised the estimation of concussion risk for almost all the investigated risk factors, except previous concussion and match play. For this reason, prospective cohort design and consistent measures of risk should be employed in future studies. Specifically, the effect of body checking using aged matched comparison groups, the effect of gender in male-dominated contact sports, genetic risk factors and the effect of age all require further research. In addition, everal neurological disorders such as migraines, encephalitis and epilepsy ${ }^{2,130}$ have been suggested to affect concussion risk but lacked sufficient research to be identified in this systematic review. Further studies are therefore required to identify whether a possible association exists between these factors and concussion. 


\section{Conclusion}

This evidence-based systematic review provides descriptive analysis of several risk factors for sports concussion (Table 3). Specifically, athletes with a history of previous sport-related concussions were at a higher risk of sustaining another concussion which is supported by the findings of the new Zurich, 2012 consensus statement ${ }^{2}$. In addition to previous concussion, match play increased concussion risk with high certainty and therefore a good estimate of risk may be established. All other risk factors have a low certainty that it associates with risk of concussion. Finally, the devastating effect on quality of life, especially in the athlete's later years, of debilitating neurological complications such as chronic traumatic encephalopathy (CTE) as a consequence of repetitive concussive head impacts are a concern. Consequently, more high quality level I studies are needed to confirm factors which may modulate concussion risk in order to reduce concussion incidence, improve management of athletes at high risk and prevent serious health complications later on.

\section{Acknowledgements}

The authors would like to thank James Brown for his assistance in risk estimate definitions.

\section{Competing interest}

The authors declare no competing interest, however AVS has filed patents regarding specific genetic sequence variants (not discussed in this manuscript) and injury risk of Achilles tendinopathy and anterior cruciate ligament ruptures. 


\section{Funding}

This work was supported, in part, with funds from the University of Cape Town and the South African Medical Research Council. SM was funded by the South African National Research Foundation (NRF). SA was funded jointly by the Deutscher Akademischer Austausch Dienst (DAAD) and NRF. MP was funded by the Thembakazi Trust.

\section{Summary: What are the new findings?}

- To our knowledge, this is the first evidence-based systematic review of concussion risk and providing descriptive evidence of potential risk factors.

- There is a high level of certainty that previous concussion(s) and match play increases risk of sustaining subsequent concussions

- Sex, playing position, playing level, behaviour, environment and mechanism of injury are all promising factors, but further research is required to establish if they are significant risk factors. 


\section{Reference List}

1 Langlois JA, Rutland-Brown W, Wald MM. The epidemiology and impact of traumatic brain injury: a brief overview. J Head Trauma Rehabil 2006;21:375-8.

2 McCrory $\mathrm{P}$, Meeuwisse WH, Aubry $\mathrm{M}$, et al. Consensus statement on concussion in sport: the 4th International Conference on Concussion in Sport held in Zurich, November 2012. Br J Sports Med 2013;47:250-8.

3 Atabaki SM. Prehospital Evaluation and Management of Traumatic Brain Injury in Children. Clin Pediatr Emerg Med 2006;7:94-104.

4 Mckee AC, Cantu RC, Nowinski CJ, et al. Chronic Traumatic Encephalopathy in Athletes: Progressive Tauopathy following Repetitive Head Injury. J Neuropathol Exp Neurol 2009;68:709-35.

5 Moser RS, Schatz P. Enduring effects of concussion in youth athletes. Arch Clin Neuropsychol 2002;17:91-100.

6 Guskiewicz KM, D P, Marshall SW, et al. Assocation between Recurrent Concussion and Late-Life Cognitive Impairment in Retired Professional Football Players. Neurosurgery 2005;57:719-26.

7 Schick DM, Meeuwisse WH. Injury rates and profiles in female ice hockey players. Am J Sports Med 2003;31:47-52.

8 Echlin PS, Tator $\mathrm{CH}$, Cusimano MD, et al. A prospective study of physician-observed concussions during junior ice hockey: implications for incidence rates. Neurosurg Focus 2010;29:E4.

9 Guskiewicz KM, Marshall SW, Bailes J, et al. Recurrent Concussion and Risk of Depression in Retired Professional Football Players. Med Sci Sports Exerc 2007;39:903-10.

10 Makdissi $M$, Davis $G$, Jordan B, et al. Revisiting the modifiers: how should the evaluation and management of acute concussions differ in specific groups? Br J Sports Med 2013;47:314-20.

11 Gavett BE, Stern RA, McKee AC. Chronic Traumatic Encephalopathy: A Potential Late Effect of Sport-Related Concussive and Subconcussive Head Trauma. Clin Sports Med 2012;30:1-10.

12 Baugh CM, Stamm JM, Riley DO, et al. Chronic traumatic encephalopathy: neurodegeneration following repetitive concussive and subconcussive brain trauma. Brain Imaging Behav 2012;6:244-54. 
13 Liberati A, Altman D, Tetzlaff J, et al. The PRISMA Statement for Reporting Systematic Reviews and Meta-Analyses of Studies That Evaluate Health Care Interventions: Explanation and Elaboration. PLoS Med 2009;6.

14 Twisk J. Basic statistical methods. In: Verhagen E, van Mechelen W, eds. Sports Injury Research. New York, NY: : Oxford University Press 2010. 19-39.

15 Dicker R. Analyzing and interpreting Data. In: Gregg M, ed. Field Epidemiology. New York, NY: : Oxford University Press 2002.

16 Rothman KJ, Greenland S, Lash TL. Modern Epidemiology. Lippincott Williams \& Wilkins 2008.

17 Posthumus $M$, Collins $M$, September A V, et al. The Intrinsic Risk Factors for $A C L$ Ruptures : An Evidence-Based Review. Phys Sportsmed 2011;39:62-73.

18 Obremskey WT, Pappas N, Attallah-Wasif E, et al. Level of evidence in orthopaedic journals. J Bone Joint Surg Am 2005;87:2632-8.

19 Wright J, Swiontkowski M, Heckman J. Introducing Levels of Evidence to The Journal. J Bone Joint Surg Am 2003;85:1-3.

20 Sawaya GF, Guirguis-blake J, Lefevre M, et al. Update on the Methods of the U . S . Preventive Services Task Force : Estimating Certainty and Magnitude of Net Benefit. Ann Intern Med 2007;147:871-5.

21 Emery CA, Goulet C, Hagel BE, et al. Risk of Injury Associated With Body Checking Among Youth Ice Hockey Players. JAMA 2010;303:2265-72.

22 Emery CA, Kang J, Schneider KJ, et al. Risk of injury and concussion associated with team performance and penalty minutes in competitive youth ice hockey. $\mathrm{Br} J$ Sports Med 2011;45:1289-93.

23 Emery C, Kang J, Shrier I, et al. Risk of injury associated with bodychecking experience among youth hockey players. CMAJ 2011;183:1249-56.

24 Schneider KJ, Meeuwisse WH, Kang J, et al. Preseason Reports of Neck Pain, Dizziness, and Headache as Risk Factors for Concussion in Male Youth Ice Hockey Players. Clin J Sport Med 2013;0:1-6.

25 Hollis SJ, Stevenson MR, McIntosh AS, et al. Incidence, risk, and protective factors of mild traumatic brain injury in a cohort of Australian nonprofessional male rugby players. Am J Sports Med 2009;37:2328-33.

26 Zemper ED. Analysis of Cerebral Concussion Frequency With the Most Commonly Used Models of Football Helmets. J Athl Train 1994;29:44-50. 
27 Zemper ED. Two-year prospective study of relative risk of a second cerebral concussion. Am J Phys Med Rehabil 2003;82:653-9.

28 Kontos AP, Elbin RJ, Collins MW. Aerobic fitness and concussion outcomes in high school football. In: Foundations of Sport-related Brain Injuries. 2006. 315-39.

29 Guskiewics KM, Mccrea M, Marshall SW, et al. Cumulative Effects Associated With Recurrent Concussion in Collegiate Football Players: The NCAA Concussion Study. JAMA 2003;290:2549-55.

30 Kristman VL, Tator $\mathrm{CH}$, Kreiger N, et al. Does the Apolipoprotein $\varepsilon 4$ Allele Predispose Varsity Athletes to Concussion? A Prospective Cohort Study. Clin J Sport Med 2008;18:322-8.

31 Delaney JS, Lacroix VJ, Gagne C, et al. Concussions among university football and soccer players: a pilot study. Clin J Sport Med 2001;11:234-40.

32 Delaney JS, Lacroix VJ, Leclerc S, et al. Concussions During the 1997 Canadian Football League Season. Clin J Sport Med 2000;10:9-14.

33 Delaney JS, Lacroix VJ, Leclerc $\mathrm{S}$, et al. Concussions among university football and soccer players. Clin J Sport Med 2002;12:331-8.

34 Dick R, Ferrara MS, Agel J, et al. Descriptive epidemiology of collegiate men's football injuries: National Collegiate Athletic Association Injury Surveillance System, 19881989 through 2003-2004. J Athl Train 2007;42:221-33.

35 Bridges EJ, Rouah F, Johnston KM. Snowblading injuries in Eastern Canada. Br J Sports Med 2003;37:511-5.

36 Nation AD, Nelson NG, Yard EE, et al. Football-related injuries among 6- to 17-yearolds treated in US emergency departments, 1990-2007. Clin Pediatr 2011;50:200-7.

37 Hinton RY, Lincoln AE, Almquist JL, et al. Epidemiology of lacrosse injuries in high school-aged girls and boys: a 3-year prospective study. Am J Sports Med 2005;33:1305-14.

38 Emery C, Tyreman H. Sport participation, sport injury, risk factors and sport safety practices in Calgary and area junior high schools. Paediatr Child Health 2009;14:43944.

39 Lincoln AE, Caswell S V, Almquist JL, et al. Trends in concussion incidence in high school sports: a prospective 11-year study. Am J Sports Med 2011;39:958-63.

40 Delaney JS, Al-Kashmiri A, Drummond R, et al. The effect of protective headgear on head injuries and concussions in adolescent football (soccer) players. Br J Sports Med 2008;42:110 - 115 . 
41 Covassin T, Swanik CB, Sachs ML. Sex Differences and the Incidence of Concussions Among Collegiate Athletes. J Athl Train 2003;38:238-44.

42 Fuller CW, Junge A, Dvorak J. A six year prospective study of the incidence and causes of head and neck injuries in international football. Br J Sports Med 2005;39:i3-9.

43 Gessel LM, Fields SK, Collins CL, et al. Concussions Among United States High School and Collegiate Athletes. J Athl Train 2007;42:495-503.

44 Deitch JR, Starkey C, Walters SL, et al. Injury risk in professional basketball players: a comparison of Women's National Basketball Association and National Basketball Association athletes. Am J Sports Med 2006;34:1077-83.

45 Wessels KK, Broglio SP, Sosnoff JJ. Concussions in wheelchair basketball. Arch Phys Med Rehabil 2012;93:275-8.

46 Castile L, Collins CL, Mcllvain NM, et al. The epidemiology of new versus recurrent sports concussions among high school athletes, 2005-2010. Br J Sports Med 2012;46:603-10.

47 Marar M, Mcllvain NM, Fields SK, et al. Epidemiology of concussions among United States high school athletes in 20 sports. Am J Sports Med 2012;40:747-55.

48 Tierney RT, Higgins M, Caswell S V, et al. Sex differences in head acceleration during heading while wearing soccer headgear. J Athl Train 2008;43:578-84.

49 Tierney R, Sitler M, Swanik C, et al. Gender Differences in Head-Neck Segment Dynamic Stabilization during Head Acceleration. Med Sci Sports Exerc 2005;37:272-9.

50 Barnes BC, Cooper L, Kirkendall DT, et al. Concussion history in elite male and female soccer players. Am J Sports Med 1998;26:433-8.

51 Dick RW. Is there a gender difference in concussion incidence and outcomes? $\mathrm{Br} \mathrm{J}$ Sports Med 2009;43:i46-50.

52 Zemper ED, Pieter W. Injury rates during the 1988 US Olympic Team Trials for taekwondo. Br J Sports Med 1989;23:161-4.

53 Pieter W, Zemper ED. Head and neck injuries in young taekwondo athletes. J Sports Med Phys Fitness 1999;39:147-53.

54 Koh JO, Cassidy JD. Incidence study of head blows and concussions in competition taekwondo. Clin J Sport Med 2004;14:72-9.

55 Emery CA, Meeuwisse WH, Hartmann SE. Evaluation of risk factors for injury in adolescent soccer: implementation and validation of an injury surveillance system. Am J Sports Med 2005;33:1882-91. 
56 Boden BP, Kirkendall DT, Garrett WE. Concussion incidence in elite college soccer players. Am J Sports Med 1998;26:238-41.

57 Kerr HA, Curtis C, Micheli $\amalg$, et al. Collegiate rugby union injury patterns in New England: a prospective cohort study. Br J Sports Med 2008;42:595-603.

58 Yang J, Phillips $\mathrm{G}$, Xiang $\mathrm{H}$, et al. Hospitalisations for sport-related concussions in US children aged 5 to 18 years during 2000-2004. Br J Sports Med 2008;42:664-9.

59 Emery CA, Meeuwisse WH, McAllister JR. Survey of sport participation and sport injury in Calgary and area high schools. Clin J Sport Med 2006;16:20-6.

60 Pellman EJ, Powell JW, Viano DC, et al. Concussion in Professional Football: Epidemiological Features of Game Injuries and Review of the Literature-Part 3. Neurosurgery 2004;54:81-96.

61 Pellman EJ, Viano DC, Casson IR, et al. Concussion in Professional Football: Repeat Injuries-Part 4. Neurosurgery 2004;55:860-76.

62 Wennberg $\mathrm{R}$ a, Tator $\mathrm{CH}$. Concussion incidence and time lost from play in the NHL during the past ten years. Can J Neurol Sci 2008;35:647-51.

63 Kemp SPT, Hudson Z, Brooks JHM, et al. The epidemiology of head injuries in English professional rugby union. Clin J Sport Med 2008;18:227-34.

64 Hinton-bayre AD, Geffen G, Friis P. Presentation and mechanisms of concussion in professional Rugby League football. J Sci Med Sport 2004;7:400-4.

65 Shields BJ, Smith G a. Cheerleading-related injuries to children 5 to 18 years of age: United States, 1990-2002. Pediatrics 2006;117:122-9.

66 Emery CA, Meeuwisse WH. Injury rates, risk factors, and mechanisms of injury in minor hockey. Am J Sports Med 2006;34:1960-9.

67 Knox CL, Comstock RD, McGeehan J, et al. Differences in the risk associated with head injury for pediatric ice skaters, roller skaters, and in-line skaters. Pediatrics 2006;118:549-54.

68 Guskiewicz KM, Weaver NL, Padua DA, et al. Epidemiology of concussion in collegiate and high school football players. Am J Sports Med 2000;28:643-50.

69 Lee AJ, Garraway WM. Epidemiological comparison of injuries in school and senior club rugby. Br J Sports Med 1996;30:213-7.

70 Lincoln AE, Hinton RY, Almquist JL, et al. Head, face, and eye injuries in scholastic and collegiate lacrosse: a 4-year prospective study. Am J Sports Med 2007;35:207-15. 
71 Labella CR, Smith BW, Sigurdsson A. Effect of mouthguards on dental injuries and concussions in college basketball. Med Sci Sports Exerc 2002;34:41-4.

72 Marshall SW, Loomis DP, Waller AE, et al. Evaluation of protective equipment for prevention of injuries in rugby union. Int J Epidemiol 2005;34:113-8.

73 Desmarteau D. Recommendations for the use of mouthguards in contact sports: can they also reduce the incidence and severity of cerebral concussions? Curr Sports Med Rep 2006;5:268-71.

74 Hagel B, Meeuwisse W. Risk Compensation: A "Side Effect" of Sport Injury Prevention? Clin J Sport Med 2004;14:193-6.

75 Hedlund J. Risky business: safety regulations, risk compensation, and individual behavior. Inj Prev 2000;6:82-9.

76 Singh GD, Maher GJ, Padilla RR. Customized mandibular orthotics in the prevention of concussion/mild traumatic brain injury in football players: a preliminary study. Dent Traumatol 2009;25:515-21.

77 Wisniewski JF, Guskiewicz K, Trope M, et al. Incidence of cerebral concussions associated with type of mouthguard used in college football. Dent Traumatol 2004;20:143-9.

78 Takeda $\mathrm{T}$, Ishigami K, Hoshina $\mathrm{S}$, et al. Can mouthguards prevent mandibular bone fractures and concussions? A laboratory study with an artificial skull model. Dent Traumatol 2005;21:134-40.

79 McCrory P. Do mouthguards prevent concussion? Br J Sports Med 2001;35:81-2.

80 Wilson BD. Protective headgear in rugby union. Sports Med 1998;25.

81 Jones SJ, Lyons RA, Evans R, et al. Effectiveness of rugby headgear in preventing soft tissue injuries to the head: a case-control and video cohort study. Br J Sports Med 2004;38:159-62.

82 Naunheim RS, Ryden A, Standeven J, et al. Does soccer headgear attenuate the impact when heading a soccer ball? Acad Emerg Med 2003;10:85-90.

83 Mclntosh AS, McCrory P, Finch CF, et al. Does padded headgear prevent head injury in rugby union football? Med Sci Sports Exerc 2009;41:306-13.

84 Benson BW, Mohtadi NG, Rose MS, et al. Head and neck injuries among ice hockey players wearing full face shields vs half face shields. JAMA 1999;282:2328-32.

85 Stuart MJ, Smith AM, Malo-Ortiguera S a, et al. A comparison of facial protection and the incidence of head, neck, and facial injuries in Junior A hockey players. A function of individual playing time. Am J Sports Med 2002;30:39-44. 
86 Gerberich SG, Finke R, Madden M, et al. An epidemiological study of high school ice hockey injuries. Childs Nerv Syst 1987;3:59-64.

87 Stephenson S, Gissane C, Jennings D. In jury in rugby league: a four year prospective survey. Br J Sports Med 1996;30:331-4.

88 Hagel BE, Marko J, Dryden D, et al. Effect of bodychecking on injury rates among minor ice hockey players. CMAJ 2006;175:155-60.

89 Marchie A, Cusimano MD. Bodychecking and concussions in ice hockey: Should our youth pay the price? CMAJ 2003;169:124-8.

90 Mahley W. Apolipoprotein E : Cholesterol Protein with Expanding Role in Cell. Science 1988;240:622-30.

91 Lynch JR, Pineda JA, Morgan D, et al. Apolipoprotein E Affects the Central Nervous System Response to Injury and the Development of Cerebral Edema. Ann Neurol 2001;51:113-36.

92 Terrell TR, Bostick RM, Abramson R, et al. APOE, APOE Promoter and Tau Genotypes and Risk for Concussion in College Athletes. Clin J Sport Med 2008;18:10-7.

93 Tierney RT, Mansell JL, Higgins M, et al. Apolipoprotein E Genotype and Concussion in College Athletes. Clin J Sport Med 2010;20:464-8.

94 World Taekwondo Federation. World taekwondo federation competition rules \& interpretation. World Taekwondo 2012.http://www.wtf.org/wtf_eng/site/rules/competition.html (accessed 22 Mar2013).

95 Koh JO, Watkinson EJ. Possible Concussions Following Head Blows in the 2001 Canadian National Taekwondo Championships Methods Participants and definition of concussion. Crossin Boundaries - an interdiscoplinary journal 2002;1:79-93.

96 Borowski L a, Yard EE, Fields SK, et al. The epidemiology of US high school basketball injuries, 2005-2007. Am J Sports Med 2008;36:2328-35.

97 Darling SR, Schaubel DE, Baker JG, et al. Intentional versus unintentional contact as a mechanism of injury in youth ice hockey. Br J Sports Med 2011;45:492-7.

98 Delaney JS, Puni V, Rouah F. Mechanisms of injury for concussions in university football, ice hockey, and soccer: a pilot study. Clin J Sport Med 2006;16:162-5.

99 Levy ML, Ozgur BM, Berry C, et al. Analysis and evolution of head injury in football. Neurosurgery 2004;55:649-55. 
100 Naunheim, Rosanne McGurren, Michael Standeven, John Fucetola, Robert Lauryssen C, Deibert E. Does the Use of Artificial Turf Contribute to Head Injuries? J Trauma 2002;53.

101 Bjørneboe J, Bahr R, Andersen TE. Risk of injury on third-generation artificial turf in Norwegian professional football. Br J Sports Med 2010;44:794-8.

102 Ekstrand J, Hägglund M, Fuller CW. Comparison of injuries sustained on artificial turf and grass by male and female elite football players. Scand J Med Sci Sports 2011;21:824-32.

103 Tegner Y, Lorentzon R. Concussion among Swedish elite ice hockey players. Br J Sports Med 1996;30:251-5.

104 Hollis SJ, Stevenson MR, Mcintosh AS, et al. Mild traumatic brain injury among a cohort of rugby union players: predictors of time to injury. $\mathrm{Br} J$ Sports Med 2011;45:997-9.

105 Nilsson M, Hägglund M, Ekstrand J, et al. Head and Neck Injuries in Professional Soccer. Clin J Sport Med 2013;0:1-6.

106 Kuzuhara K, Shimamoto H, Mase Y. Ice Hockey Injuries in a Japanese Elite Team : A 3year Prospective study. J Ath/ Train 2009;44:208-14.

107 Agel J, Dick R, Nelson B, et al. Descriptive Epidemiology of Collegiate Women's Ice Hockey Injuries: National Collegiate Athletic Association Injury Surveillance System, 2000-2001 Through 2003-2004. J Athl Train 2007;42:249-54.

108 Agel J, Olson DE, Dick R, et al. Descriptive Epidemiology of Collegiate Women's Basketball Injuries: National Collegiate Athletic Association Injury Surveillance System, 1988-1989 Through 2003-2004. J Athl Train 2007;42:202-10.

109 Dick R, Hootman JM, Agel J, et al. Descriptive Epidemiology of Collegiate Women's Field Hockey Injuries: National Collegiate Athletic Injury Surveillance System, 1981989 Through 2002-2003. J Athl Train 2007;42:211-20.

110 Dick R, Lincoln AE, Agel J, et al. Descriptive Epidemiology of Collegiate Women's Lacrosse Injuries: National Collegiate Athletic Association Injury Surveillance System, 1988-1989 Through 2003-2004. J Athl Train 2007;42:262-9.

111 Dick R, Hertel J, Agel J, et al. Descriptive Epidemiology of Collegiate Men's Basketball Injuries: National Collegiate Athletic Association Injury Surveillance System, 19881989 Through 2003-2004. J Athl Train 2007;42:194-201.

112 Marar M, Mcllvain NM, Fields SK, et al. Epidemiology of concussions among United States high school athletes in 20 sports. Am J Sports Med 2012;40:747-55. 
113 Agel J, Evans TA, Dick R, et al. Descriptive epidemiology of collegiate men's soccer injuries: National Collegiate Athletic Association Injury Surveillance System, 19881989 through 2002-2003. J Athl Train 2007;42:278-85.

114 Agel J, Dompier TP, Dick R, et al. Descriptive epidemiology of collegiate men's ice hockey injuries: National Collegiate Athletic Association Injury Surveillance System, 1988-1989 through 2003-2004. J Athl Train 2007;42:241-8.

115 Dick R, Romani WA, Agel J, et al. Descriptive epidemiology of collegiate men's lacrosse injuries: National Collegiate Athletic Association Injury Surveillance System, 1988-1989 through 2003-2004. J Athl Train 2007;42:255-61.

116 Dick R, Putukian M, Agel J, et al. Descriptive Epidemiology of Collegiate Women's Soccer Injuries: National Collegiate Athletic Association Injury Surveillance System, 1988-1989 Through 2002-2003. J Athl Train 2007;42:278-85.

117 Marshall SW, Hamstra-wright KL, Dick R, et al. Descriptive Epidemiology of Collegiate Women's Softball Injuries : National Collegiate Athletic Association Injury Surveillance System , 1988 - 1989 Through 2003 - 2004. 2007;42:286-94.

118 Booher MA, Wisniewski J, Smith BW, et al. Comparison of reporting systems to determine concussion incidence in NCAA Division I collegiate football. Clin J Sport Med 2003;13:93-5.

119 Goodman D, Gaetz M, Meichenbaum D. Concussions in hockey: there is cause for concern. Med Sci Sports Exerc 2001;33:2004-9.

120 Marshall SW, Spencer RJ. Concussion in rugby: the hidden epidemic. J Athl Train 2001;36:334-8.

121 Dick R, Sauers EL, Agel J, et al. Descriptive epidemiology of collegiate men's baseball injuries: National Collegiate Athletic Association Injury Surveillance System, 19881989 through 2003-2004. J Athl Train 2007;42:183-93.

122 Agel J, Palmieri-smith RM, Dick R, et al. Descriptive Epidemiology of Collegiate Women's Volleyball Injuries: National Collegiate Athletic Association Injury Surveillance System, 1988-1989 Through 2003-2004. J Athl Train 2007;42:295-302.

123 Marshall SW, Covassin T, Dick R, et al. Descriptive Epidemiology of Collegiate Women's Gymnastics Injuries: National Collegiate Athletic Association Injury Surveillance ystem, 1988-1989 Through 2003-2004. J Athl Train 2007;42:234-40.

124 Gabbett TJ. Influence of training and match intensity on injuries in rugby league. J Sports Sci 2004;22:409-17.

125 Covassin T, Swanik CB, Sachs ML. Epidemiological Considerations of Concussions Among Intercollegiate Athletes. Appl Neuropsychol Adult 2003;10:12 - 22. 
126 Leininger RE, Knox CL, Comstock RD. Epidemiology of 1.6 million pediatric soccerrelated injuries presenting to US emergency departments from 1990 to 2003. Am J Sports Med 2007;35:288-93.

127 Macpherson A, Rothman L, Howard A. Body-checking rules and childhood injuries in ice hockey. Pediatrics 2006;117:e143-7.

128 Gissane $C$, Jennings $D$, Kerr $\mathrm{K}$, et al. Injury rates in rugby league football: impact of change in playing season. Am J Sports Med 2003;31:954-8.

129 Koh JO, Cassidy JD, Watkinson EJ. Incidence of concussion in contact sports: a systematic review of the evidence. Brain Injury 2003;17:901-17.

130 Kutcher JS, Eckner JT. At-risk populations in sports-related concussion. Curr Sports Med Rep 2010;9:16-20.

131 Gordon KE, Dooley JM, Wood EP. Is migraine a risk factor for the development of concussion? Br J Sports Med 2006;40:184-5. 